\title{
Review \\ Extremes Rainfall Events on Riparian Flora and Vegetation in the Mediterranean Basin: A Challenging but Completely Unexplored Theme
}

\author{
Maria Silvia Pinna *, Maria Cecilia Loi ${ }^{D}$, Giulia Calderisi and Giuseppe Fenu \\ Department of Life and Environmental Sciences, University of Cagliari, Viale S. Ignazio da Laconi 13, \\ I-09123 Cagliari, Italy; loimc@unica.it (M.C.L.); giulia.calderisi@gmail.com (G.C.); gfenu@unica.it (G.F.) \\ * Correspondence: m.silviapinna@gmail.com
}

Citation: Pinna, M.S.; Loi, M.C.; Calderisi, G.; Fenu, G. Extremes Rainfall Events on Riparian Flora and Vegetation in the Mediterranean Basin: A Challenging but Completely Unexplored Theme. Water 2022, 14, 817. https://doi.org/10.3390/ w14050817

Academic Editor: Aizhong Ye

Received: 2 February 2022

Accepted: 3 March 2022

Published: 5 March 2022

Publisher's Note: MDPI stays neutral with regard to jurisdictional claims in published maps and institutional affiliations.

Copyright: (c) 2022 by the authors. Licensee MDPI, Basel, Switzerland. This article is an open access article distributed under the terms and conditions of the Creative Commons Attribution (CC BY) license (https:// creativecommons.org/licenses/by/ $4.0 /)$.

\begin{abstract}
In a global climate change scenario "Extreme climatic events" are expected to widely affect flora and vegetation in Med-regions, especially "Extremes Rainfall Events" which will have impacts on riparian environments. Aiming to provide an in-depth picture on the effects of these events on the riparian flora and vegetation in the Mediterranean Basin, especially focusing on islands, a bibliographic search was performed in the main international databases, which led to 571 articles published from 2000 to 2021. Most studies have analyzed these phenomena from the climatic point of view identifying three main topics "Rainfall", "Global/Climate change", and "Flood". 81 papers concerned effects of extreme events on Mediterranean woodland formations and cultivated plants. A further analysis focused on European countries and Mediterranean bioregion using "Extreme rainfall events" and "Extreme rainfall and floods" as keywords. A low number of records relating to Mediterranean island regions was found, having Sicily as the study area. Moreover, seven articles had Sardinia as a study area, four of which referred to flora and vegetation. A lack of studies on the effects of extreme rainfall events on riparian flora and vegetation were highlighted. This review constitutes a call for researchers to explore extreme phenomena that have become recurrent in the Mediterranean Basin.
\end{abstract}

Keywords: climate change; extreme climatic phenomena; medicanes; flood; Mediterranean islands; riparian flora; riparian habitat; rainfall; Sardinia

\section{Introduction}

Climate change can be defined as changes in average climatic conditions on a global or regional scale and it is the result of the synergy between the natural climate variability and all modifications in the composition of the atmosphere mainly attributable to human activities [1]. The Global Climate Observing System (GCOS), established in 1992 with the aim to monitor the climate and facilitate the development and improvement of global climate observations, has identified a series of physical, chemical and biological variables (called Essential Climatic Variables-ECVs) referred to the atmosphere, lands and oceans, which represent the basic data needed for the characterization of the Earth's climate, understanding its evolution, assessing risks and dictating mitigation and adaptation measures needed [2]. These ECVs are the tools to monitor the most characteristic factors of climate change, the composition of the modified atmosphere and global warming because of the increase in greenhouse gases (GHGs), but also the responses of both terrestrial and marine environments and the effects on the ecosystem services they provide us [2]. However, to date it is unanimously accepted that the change in climate patterns is mainly caused by GHGs derived from sources of natural emissions (linked to forest fires, oceans, permafrost, wetlands, volcanoes and earthquakes) and human activities mainly related to energy production (the use of fossil fuels such as with coal, petroleum derivatives and natural gas), industrial activities, forestry, land use and land use change [3-5]. In fact, in 
the so called "Anthropocene" era, GHGs generated by human activities have determined a relevant increase in the concentrations of carbon dioxide $\left(\mathrm{CO}_{2}\right)$, methane $\left(\mathrm{CH}_{4}\right)$ and nitrous oxide $\left(\mathrm{N}_{2} \mathrm{O}\right)$ in the atmosphere [3] (IPCC, 2014). Linked to this phenomenon the human-induced warming is growing $0.1-0.3{ }^{\circ} \mathrm{C}$ per decade as a result of past and current emissions, in fact the global mean surface temperature registered for the decade 2006-2015 was c. $0.75-0.99{ }^{\circ} \mathrm{C}$ higher than the average over the $1850-1900$ period [1]. The last six years, 2016-2020, were probably the six hottest on record, and in the last five years (2016-2020) and 10 years (2011-2020) the warmest averages were recorded [2]. However, temperature anomalies are not identical across the globe since most terrestrial areas were warmer than average in the 1981-2010 range. Conversely, most of the energy accumulated in the Earth system is absorbed by the oceans with a strong warming trend [6]: in the last 50 years about $93 \%$ of the heat excess has been transferred to ocean water masses and the remaining $7 \%$ has heated the atmosphere and the continents contributing to the melting of sea and land ice [7]. The same trend of rising Sea Surface Temperature was recorded in the Mediterranean Sea [8]. This phenomenon has led to a rise in sea level derived from the mass loss from glaciers and ice caps with the strongest regional trends in the southern hemisphere. The global increase in temperature together with the rise in anthropogenic gas emissions also contribute to the lowering of the $\mathrm{pH}$ of seas, limiting the oceans' capacity to absorb about a third of global $\mathrm{CO}_{2}$ emissions $[9,10]$. The rate at which ocean acidity has intensified over the past few decades (100 times faster than natural events in the last 55 million years) exacerbates the impact of these phenomena on marine ecosystems [10-12].

In this alarming situation, in the IPCC-AR5 (Fifth Assessment Report) [3], the $1.5^{\circ} \mathrm{C}$ scenarios above pre-industrial levels and related global greenhouse gas emission pathways have been presented [13]; these scenarios indicate that to limit warming to $1.5^{\circ} \mathrm{C}$ above pre-industrial levels it is necessary to achieve net zero $\mathrm{CO}_{2}$ emissions globally around 2050, and a strong reduction in non- $\mathrm{CO}_{2}$ forcing emissions as well [2]. These perspectives have brought a widespread awareness of the problem worldwide, as well as the need for urgent coordinated actions. Subsequently in recent years there has been a slowdown in GHGs emission. Although they are different from country to country, emissions are declining in some developed countries while they are still growing in less industrialized countries (non-OECD countries) [14]. A significant decline in GHGs emissions was recorded in European countries with a level, recorded in 2018, 25.2\% lower than in 1990. This decline can be attributed to various factors including the effects of policy choices, both in the EU and in each member country, the main agricultural and environmental policies in the 1990s and those on climate and energy over the last two decades [15,16].

Despite this increased awareness worldwide and ongoing efforts, the effects of climate change are occurring with increasing frequency and magnitude. Specifically, some meteorological events occur with greater frequency, intensity, more spatially extended and with a longer duration and timing: the so called "extreme events"; these events are characterized by extreme weather conditions, rare in a certain place and time of year and persistent even for long periods of time [17]. Heat waves, cold spells, droughts, extreme rainfall events, floods, cyclones and fires have been linked to human activities [3] revealing a high degree of vulnerability of ecosystems and human society. The impacts produced by extreme events, in fact, concern not only the alteration of natural ecosystems, but cause damage to infrastructures and settlements, heavily affecting human life [18-26]. Future projections indicate that such phenomena are expected to have a particularly strong effect on Med-regions [27], showing an exacerbation of drought conditions and an increase in the frequency of extreme events greater than the global average [28-32].

In this framework, the Mediterranean Basin is recognized as an area among the most affected by the global warming. This area represents an interesting laboratory for its geological, climatic characteristics and high biodiversity and for the role it plays in the neighboring areas for hydrological exchanges with the Black Sea and the Atlantic Ocean and the European climate $[30,33,34]$. The climate of the Mediterranean Basin which is characterized by variability both in space and in time of temperatures and precipitations, 
is attributed to the geographical position, at the south-eastern limit of the routes of the North Atlantic storms, to the influence caused by the tropical and subtropical systems and last but not least, to the complex morphologies of the territory, the orography and the presence of islands and peninsulas. [35-37]. With an average temperature rise in the Mediterranean Basin, a decrease in precipitation is projected, along with an increase in the frequency and duration of the drought and desertification [24,30,32,38]. Specifically, projections on future precipitation show a decrease of $28 \%$ in summer by the end of 21 st century, important seasonal differences and a North-South dipole with the wetter northern regions and the already dry southern regions becoming even drier. The Mediterranean Sea will become warmer with consequent variations in the thermohaline circulation and salinity with probable consequences on the exchange of water and heat with the Atlantic Ocean $[30,35,36,39]$. However, the analyses on different datasets and metrics considered have shown some uncertainties in the projections, highlighting a worsening scenario at local scale, negatively influenced by local forcing such as topography [30,39]. In fact, within the Mediterranean Basin, some differences in projection were detected between the northern and southern areas [40]: an overall global trend towards longer periods of drought and shorter periods of rain [24,32] accompanied by an increase of 7.3-5.0 days for the dry period, by degree of global warming, were measured respectively for the south and north of the Mediterranean. These data highlight critical issues related to the Mediterranean area that will evolve in the future different levels of risk linked to water scarcity, increasing the already critical socio-economic contrasts between North and South [40].

\subsection{Extreme Rainfall Events (EREs)}

All scenarios indicate an increase in extreme rainfall events for the Mediterranean Basin, although not uniformly distributed for the whole area. In fact, the distribution of extreme rainfall events (EREs) shows a seasonal differentiation between the Western and Eastern part of the Mediterranean, the first affecting in autumn and the second in winter. EREs are often linked to thunderstorm or cyclonic formations, which in fact, are predicted to increase in frequency and magnitude due to climate change [41].

The Mediterranean Basin is unanimously considered one of the main cyclogenetic areas in the world, affected by rare types of cyclonic storms known as "Mediterranean tropical-like cyclones" or "Medicanes", a neologism obtained from the union of the two terms MEDIterranean and HurriCANES [42-44]. Medicanes are caused by synergies of different environmental factors such as low wind shear, high humidity and vorticity [45]. Some features detected by satellite images show similarity to tropical cyclones, albeit smaller in size, equal to a few hundred $\mathrm{km}$, the presence of a spiral-shaped cloud with an "eye" in the center, strong winds and a warm core [44,46-48]. Although characterized by much lower intensity of winds than tropical cyclones, Medicanes still represent a strong threat to islands and coastal regions [49,50].

Medicanes have attracted the attention of researchers and an interesting debate is involving in the scientific community on their reliable definition and classification $[45,46,51-59]$. In fact, in the last years, several studies have investigated different aspects of these phenomena: characteristics and conditions of formation [60,61], climatological properties [45,51,62], numerical models or simulations [42,63-68].

Medicanes occur with a frequency of about 1.5 events per year throughout the Mediterranean Basin $[45,49,69]$, with an annual distribution with the highest frequency records between September and March, a slight decrease in spring and little activity (tending to zero) in the hottest months of July and August $[49,61,69]$. As for the (often correlated) extreme rainfall events, not all areas of the Mediterranean Basin are equally affected by the formation of Medicanes as the environmental conditions necessary for their formation have to occur together $[45,61]$ : the most common regions in which they occur are the Western Mediterranean Basin (Balearic Islands, coast of Spain, south of France and the Western coast of Corsica and Sardinia), the widest part of the Ionian Sea (between Sicily and Greece, covering the Ionian Sea until the Lybian coast) and a limited presence is recorded in the 
Aegean Sea and in the Eastern Mediterranean [44,48,61,65,69]. However, this distribution is constantly evolving and the projections indicate by the end of the century a decrease of Medicanes up to $40 \%$ compared to the present $[49,50,70]$. Moreover, a different spatial distribution in the localization of Medicanes is expected reaching a more or less uniform distribution at the end of the century over the entire Basin [70]. Although fewer in number, more intense events, more violent winds and more intense precipitations typical of tropical storms are expected to occur $[49,55]$.

In addition to considering the frequency and the future changes in the distribution of such phenomena, one of the main consequences of a Medicane, hitherto little investigated, is linked to the abrupt effects of the correlated extreme and uncommon rainfall events on the riparian ecosystems, directly affected by these events: such consequences can include both mechanical damages, due to the large mass of water in a short space of time, and long-term consequences such as the modification/replacement of riparian ecosystems. Water-based plant communities in Mediterranean regions are in fact particularly sensitive to the expected effects of climate change in the coming decades. Moreno-Rodríguez et al. [71] in a study focusing on the overall effects of climate change in Spain also described such effects at the water-based ecosystem level and riparian plant communities. According to this study, climate change will affect water-based ecosystems in terms of decreasing their surface area until they disappear. In addition, temporary and seasonal variations in river flows are expected, including a decrease in riparian plant biodiversity [71].

\subsection{Riparian Habitats}

Riparian zones are among the most complex ecological systems in the biosphere, often heterogeneous, highly dynamic and highly threatened [72,73]. Therefore, these zones are difficult to classify into predictable systemic entities, as well as to monitor and manage [72-74] and, as a consequence, this natural complexity brought the mismanagement of riparian zones worldwide and often the degradation of their woodland formations $[73,75]$. Riparian zones represent the interface between aquatic and terrestrial ecosystems: they are areas that include the stream channel between the low and high watermarks and the part of the terrestrial landscape from the high-water mark toward the uplands where vegetation may be influenced by high water tables or flooding and by the capacity of the soils to retain water $[72,74,76,77]$. Riparian zones have peculiar ecological features that reflect the aquatic-terrestrial interaction; thus, their boundaries can be delineated by changes in soil conditions, vegetation, and other factors [74,77]. These zones are affected by fluvial processes such as flooding and deposition of alluvial soil, and typically support a distinctive flora that differs in structure and function from adjacent terrestrial vegetation [72,74,76-79]. Specifically, riparian vegetation, e.g., floodplain vegetation or vegetation directly adjacent to rivers and streams, influences several ecological functions of aquatic habitats, such as providing food, moderating stream water temperature by evapotranspiration and shading, providing a buffer zone that filters sediments and controls nutrients, and stabilizes stream banks [72,74,80,81]. Moreover, riparian zones represent key systems for regulating aquaticterrestrial linkages $[72,74,82,83]$ which may provide early indications of environmental change $[74,84,85]$.

In the Mediterranean Basin, distribution patterns of riparian flora showed a strong association with local climate, and the latter was mainly related to the change in the floristic composition between riparian sites [72,86,87]. In such context, the flora and vegetation of Mediterranean riparian ecosystems are not strictly defined as "azonal", but as "semi-azonal", in which the truly aquatic and hygrophilous species are few, while those well-suited to marked edaphic dryness are frequent [72,86]. Furthermore, in riparian environments, two variables such as biogeographic location and the longitudinal gradient, are strongly linked and associated with climate change [72,86].

Riparian communities are directly influenced by the climate $[72,87,88]$ due to physiological effects on organisms, limiting their populations and favoring certain life forms and 
phytogeographical elements [89-91]. Particularly, riparian flora shows peculiar features within the Mediterranean bioclimatic and biogeographic region $[90,92]$.

In a global change scenario, linked riparian and stream communities are likely to be deeply modified by predicted increases in the synergistic actions of connected extreme events, such as prolonged droughts, increased wildfires, and intense floods accompanying climate change [93]. It is expected that Mediterranean rivers will be affected by changes in community richness and composition, modifications of life-history traits, up to local and regional extinctions [94]. This is mainly due to the avoidance strategies against drought in med-rivers species which are more common than endurance ones, as these are relict species of colder times [95,96]. In fact, riparian vegetation in Med-rivers exhibit many drought avoidance strategies, such as higher root biomass, small leaf sizes, or more frequent branch abscission [97] while no adaptation strategies to brutal events such as an ERE are evident. Moreover, extreme events cause changes in streamflow in Med-rivers: riparian vegetation is adapted to patterns of streamflow disturbances. The attributes of the streamflow regime which govern riparian vegetation dynamics in Mediterranean regions rivers are influenced by the seasonality and variability of precipitation with dry summers and mild winters, and large interannual variability [98]. Med-rivers hydrological regimes being naturally exposed to extreme events, range from no or low flows to flash floods $[99,100]$. Temporary reduction in water availability is the main driving force behind adaptations to Mediterranean riparian vegetation to such conditions [101]. Therefore, although riparian vegetation may be affected by extreme streamflow disturbances (at plant functional diversity level), the adaptations of local riparian flora in Mediterranean rivers made these effects smaller [98].

In addition to the effects of extreme rainfall events per se, other aspects that contribute to increasing the magnitude of such phenomena must be considered, such as the geographical characteristics due to a varied typology of substrates and soil, altered in many ways and, not least, the ever-increasing coastal urbanization. The combination of all these factors and phenomena will certainly have a strong impact on riparian flora and structure, composition, and succession of riparian vegetation. [27,102].

Although riparian habitats are essential for the maintenance of biodiversity, biogeochemical cycles and ecosystem services which they provide and despite the fact that they are protected by international directives (e.g., Habitat Directive), the attention paid to these environments is still insufficient and there are still knowledge gaps on riparian ecosystems and vegetation that are linked to cumulative impacts to small ephemeral streams and large regulated rivers, as well as understudied ecosystems in the Western Mediterranean Basin [97]. Despite these considerations, there is a lack of an overview of the state of the studies on the specific effects of extreme rainfall events on riparian flora and vegetation at Mediterranean Basin level. For these reasons, our main aim was to provide an in-depth picture of the research carried out in the last 20 years on the effects of extreme rainfall events on the riparian flora and vegetation in the Mediterranean Basin, with a particular focus on the Mediterranean islands and selecting Sardinia as a study case.

\section{Materials and Methods}

To obtain an exhaustive picture on the effects of extreme rainfall events (including Medicanes and floods) on the riparian environments present in the Mediterranean Basin, a two-step in-depth research on the available literature was conducted. Such research was mainly collected from international peer-reviewed papers found via online scientific databases, namely Scopus, Web of Science, and Google Scholar by first crossing different primary keywords "Climate global change", "Extreme events", "Medicanes", "Floods impacts", "Thunderstorms", in combination with second keywords including "Mediterranean riparian vegetation" and "Mediterranean riparian flora". Subsequently, a second step of bibliographic research was carried out on Scopus using keywords like "Extreme rainfall and floods" and "Extreme rainfall events" in combination with "Mediterranean Basin". The time interval was set at 20 years from 2000 to 2021 in both cases and the results obtained were analyzed separately. 


\section{Results and Discussion}

The research on the effects of extreme rainfall events in the Mediterranean Basin produced two different matrices by using the keywords "Extreme rainfall events" (461 articles; Supplementary S1) and "Extreme rainfall and floods" (156 articles; Supplementary S2); as expected, in the two matrices we found several overlapping papers (47 articles) and thus the total of the references relating to the effects of extreme rainfall events in the Mediterranean Basin is of 571 articles (Table 1). The number and distribution of articles per year in the period considered were reported in Figure 1.

Table 1. Total articles relating to the effects of extreme rainfall events in the Mediterranean Basin. The articles were classified into category and sub-category, and the number of articles in each category was indicated.

\begin{tabular}{|c|c|c|}
\hline Category & Sub-Category & No. Articles \\
\hline \multirow{8}{*}{ Rainfall events } & Modelling & 36 \\
\hline & Estimates by radar & 8 \\
\hline & Rainfall pattern & 54 \\
\hline & Rainfall distribution & 8 \\
\hline & Torrential precipitation events & 71 \\
\hline & Precipitation effect on animals & 1 \\
\hline & Vegetation & 14 \\
\hline & & Total: 192 \\
\hline \multirow{10}{*}{ Floods } & Vegetation & 4 \\
\hline & Flood forecasting systems & 18 \\
\hline & Flood models & 19 \\
\hline & Flood frequency & 5 \\
\hline & Flood events: study cases & 30 \\
\hline & Flooding hazard/risk & 16 \\
\hline & Flood distribution & 2 \\
\hline & Socio-economic effects floods & 4 \\
\hline & Ecological response of floods & 3 \\
\hline & & Total: 101 \\
\hline \multirow{8}{*}{ Storm } & Vegetation & 2 \\
\hline & Storm/cyclone & 2 \\
\hline & Storm model/estimate/forecasting & 9 \\
\hline & Storm events & 7 \\
\hline & Storm impact & 2 \\
\hline & Thunderstorm & 1 \\
\hline & Rainstorm & 1 \\
\hline & & Total: 24 \\
\hline Medicane & & 2 \\
\hline \multirow{4}{*}{ Extreme weather events } & Vegetation & 4 \\
\hline & Extreme events model/assessment & 25 \\
\hline & Extreme events & 3 \\
\hline & & Total: 32 \\
\hline
\end{tabular}


Table 1. Cont.

\begin{tabular}{|c|c|c|}
\hline Category & Sub-Category & No. Articles \\
\hline \multirow{6}{*}{ Drought } & Vegetation & 18 \\
\hline & Drought pattern & 4 \\
\hline & Drought events & 6 \\
\hline & Animal resilience to drought & 1 \\
\hline & Drought assessment & 1 \\
\hline & & Total: 30 \\
\hline \multirow{8}{*}{ Global/Climate change } & Vegetation & 34 \\
\hline & Global/climate change & 35 \\
\hline & Climate change on crops & 12 \\
\hline & Climate change simulation & 22 \\
\hline & $\begin{array}{l}\text { Climate change on precipitation, flood, } \\
\text { water ecosystems }\end{array}$ & 27 \\
\hline & Climate change on animal & 3 \\
\hline & $\begin{array}{l}\text { Climate change } \\
\text { forecasting/risk/assessment }\end{array}$ & 41 \\
\hline & & Total: 174 \\
\hline \multirow{4}{*}{ Fires } & Vegetation & 6 \\
\hline & Fire effects & 5 \\
\hline & Fire models & 1 \\
\hline & & Total: 12 \\
\hline Lightning & & 3 \\
\hline Temperature & & 2 \\
\hline
\end{tabular}

As expected, it is noteworthy to highlight a continuous growth in the number of articles in the last twenty years with a significant increase, from 2015 to 2021. This indicates a great and constantly increasing interest of the scientific community in extreme rainfall events occurring in the Mediterranean Basin, in particular from the second half of the last decade. The pioneers published articles mainly regarding the rainfall modelling and pattern [103-112], analysis and reconstruction of flood events [113-117], and climate change numerical simulations and scenarios' assessment [118-120]. This suggests that researchers initially focused their studies on understanding and describing the causes of these phenomena, in order to gain a detailed knowledge of them and improve assessment and forecasting.

The main topics of the selected articles were particularly heterogeneous, so much so that they had to be classified into categories and each category into subcategories in order to be able to schematize them (Table 1). Among the ten main categories identified, only three are particularly rich in references, "Rainfall events", "Global/Climate change" and "Flood" with 192, 173 and 101 articles respectively.

In the "Rainfall events" category, part of the total references focuses on extreme precipitation events of torrential nature (71 articles), but the greater part is addressed to the analysis of the distribution of rainy events, their estimation with radar, specific studies on rainfall pattern and modelling (106 items). 


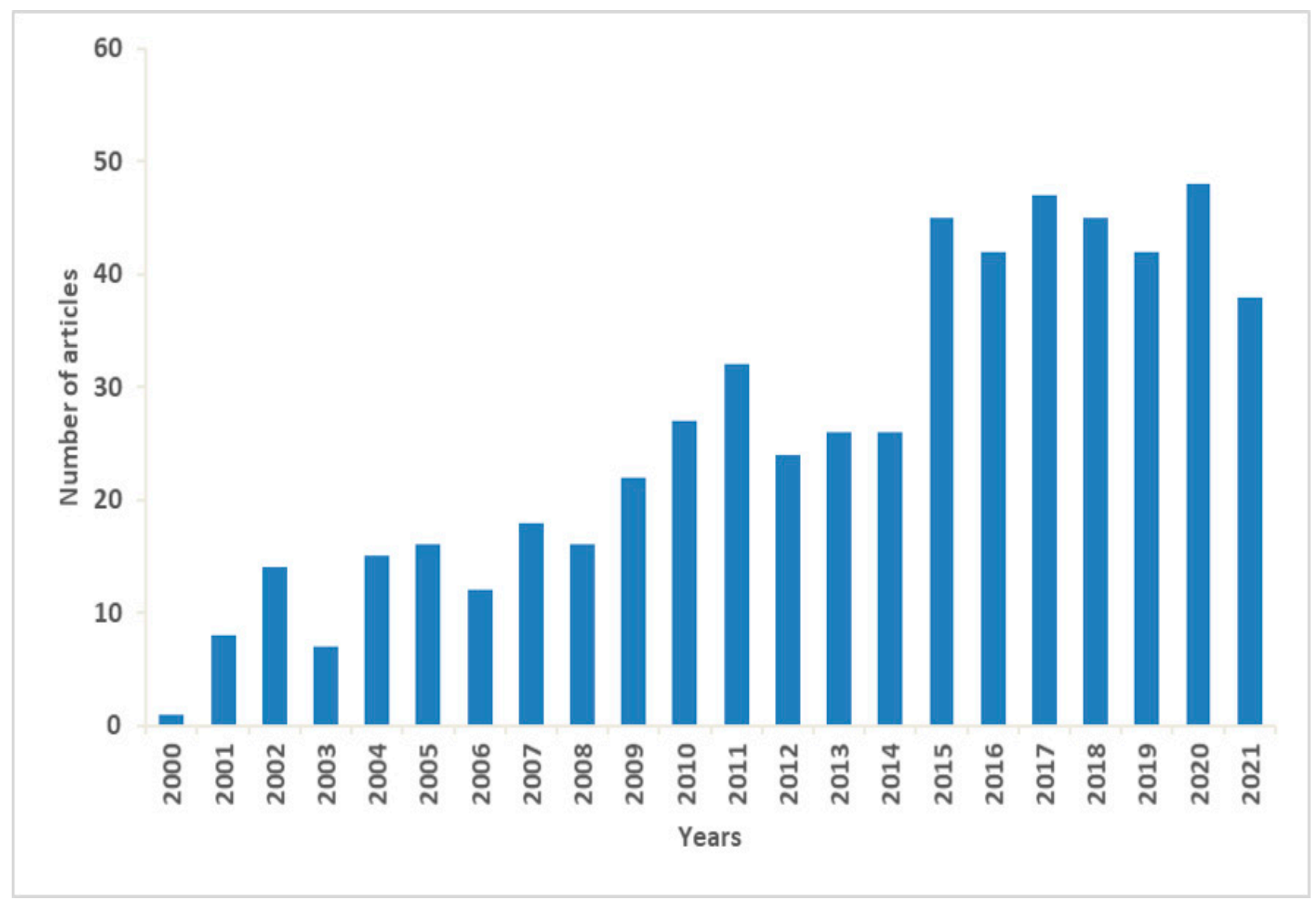

Figure 1. Number of articles on the effects of extreme rainfall events in the Mediterranean Basin published from 2000 to $2021(n=571)$.

The more general aspects of climate change but above all the effects of climate change as a cause of extreme rainfall, floods, effects on aquatic ecosystems, vegetation and agricultural ecosystems are the issues that characterize the "Global/Climate change" category (72 articles in total). At the same time, researchers place good emphasis on assessments of climate change in terms of risks and to provide reliable forecasts ( 41 articles) and models for the assessment of extreme events.

The "Flood" category includes research on the distribution and frequency of events, case studies in urban areas (37 articles), but above all flood models, forecasting systems, analyses of flooding hazard and risk especially in urban areas (53 articles). Furthermore, it is important to underline that in this type of study the economic, ecological and vegetational aspects linked to alluvial phenomena are investigated (12 articles). Few articles concern the Storm/Medicanes ( 9 articles) and Fires (12 articles in total) categories. The first ones mainly focused on storm models, event estimation and forecasting; the second ones, concerned the effects of fires (5) in general, and on vegetation (6), in particular.

\subsection{Step Two: "Extreme Rainfall Events" and "Extreme Rainfall and Floods"}

The second step of bibliographic research, as for the articles on "Extreme rainfall events", highlighted a growing trend of published papers throughout the period considered (Figure 2). 


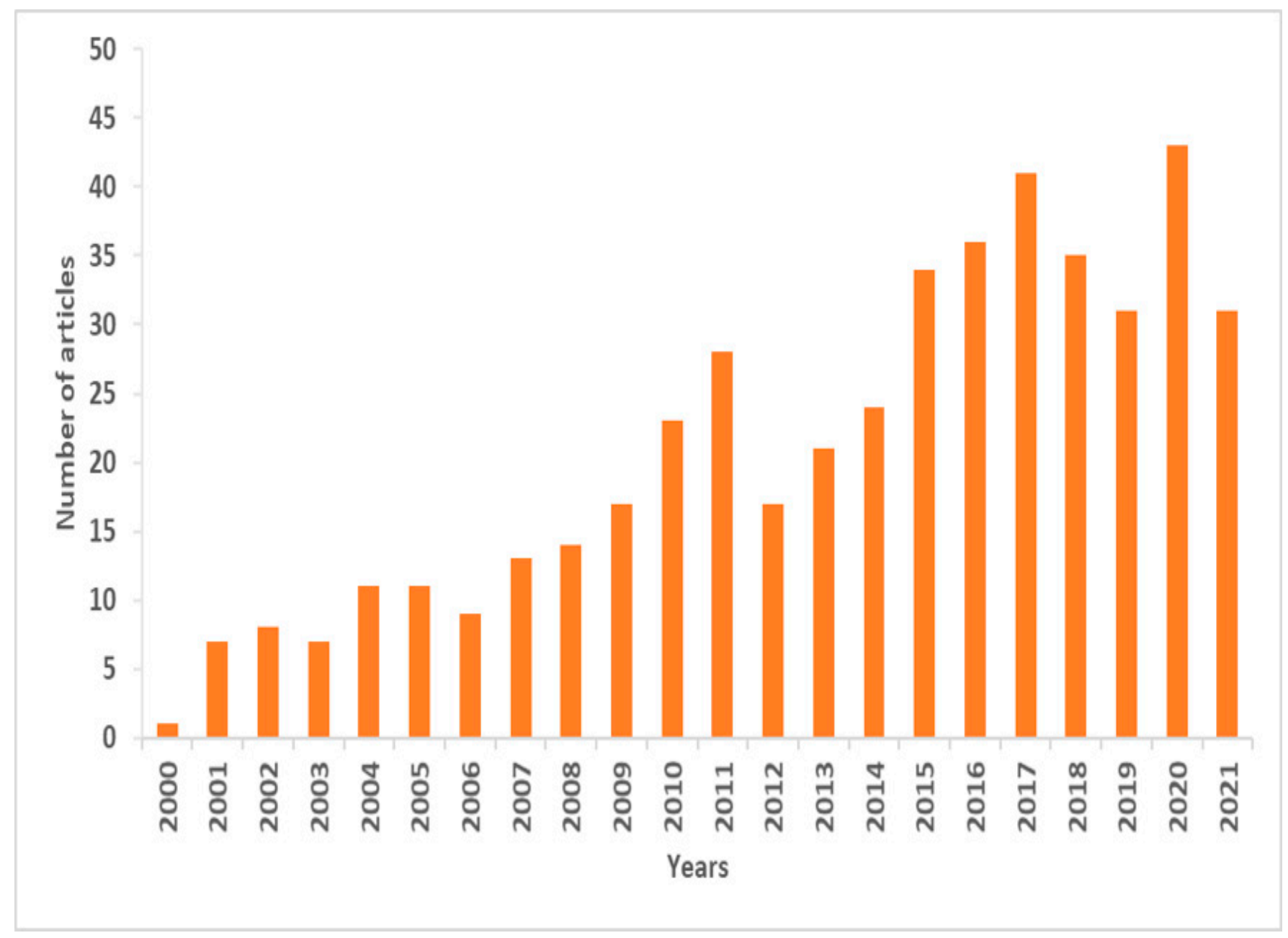

Figure 2. Number of articles on "Extreme rainfall events" published from 2000 to 2021 ( $n=462)$.

In particular, these articles have recorded a significant increase almost continuously from 2015 to 2021 (Figure 2). Again, this indicated a great interest of scientific community in extreme rainfall events, especially in the second half of the last decade.

In order to understand if there was a geographic context for "Extreme rainfall events", all articles on this topic have been grouped based on geographical distribution (Figure 3). Specifically, the study area of most of the articles included European countries; despite this, there was a part of articles we categorized as "undefined" study area, which included both those with the wider specific investigated area encompassing in other groups and those without a defined area $(15 \% ; 69$ articles) and articles relating to Extra European countries (12\%; 53 articles). Among European countries, the articles grouped at level of bioregions (sensu Habitat Directive 92/43/EEC; https: / / ec.europa.eu/environment/nature/natura2 000 /biogeog_regions/, accessed on 15 December 2021), indicated that most of them concern the Mediterranean bioregion (66\%; 307 articles), followed by the Continental ( $6 \% ; 28$ articles) and Alpine (1\%; 5 articles) bioregions.

A focus was made on the articles with Mediterranean bioregion and the articles of such area were divided into two categories, continental and insular. We found that most of the articles on "Extreme rainfall events" (92\%; 283 articles) concerned the continental territories, while only $8 \%$ (23 articles) the insular territories (Figure 4 ). 

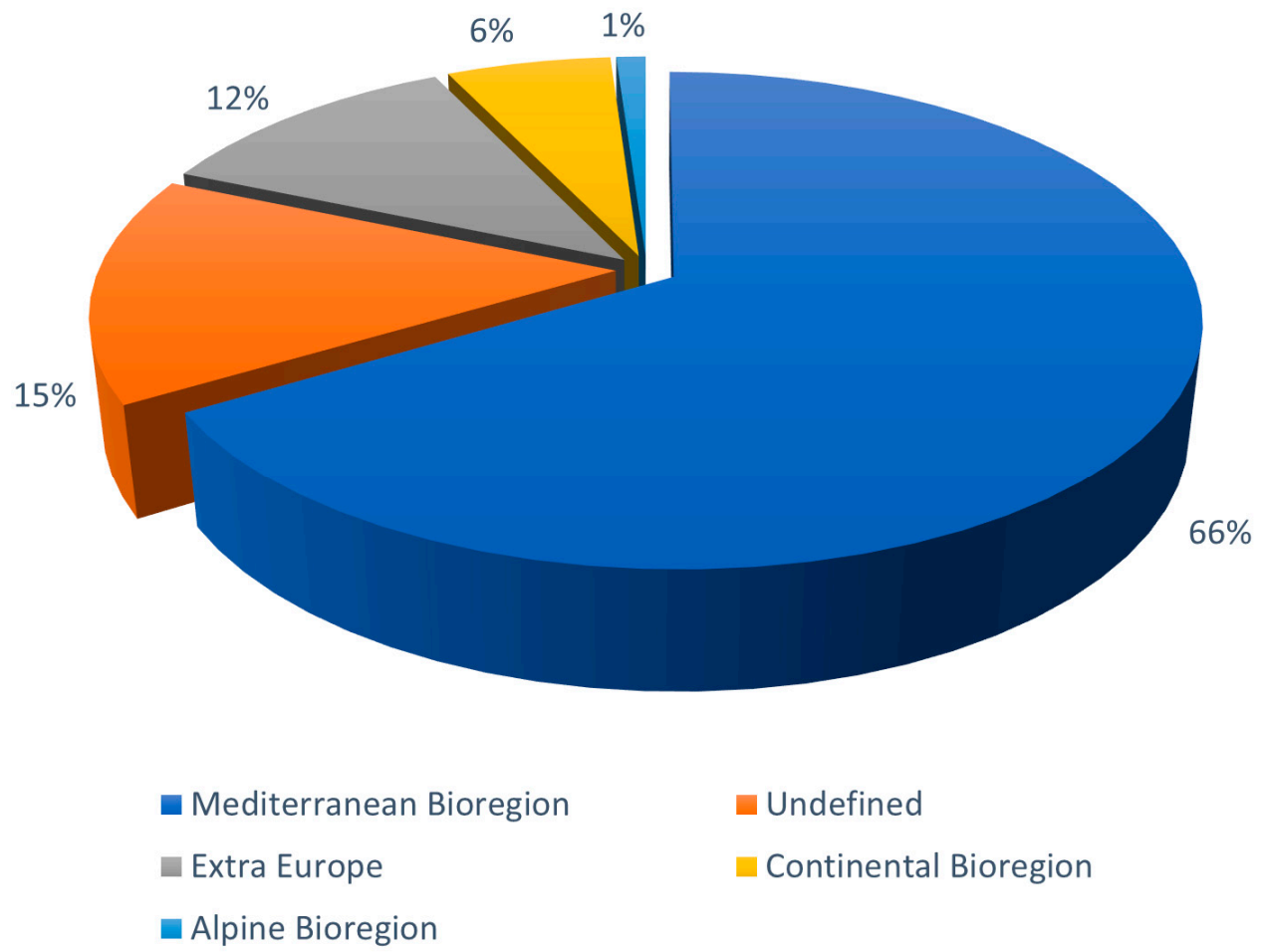

- Undefined

Continental Bioregion

Figure 3. Percentage of all "Extreme rainfall events" articles grouped by their geographical distribution.

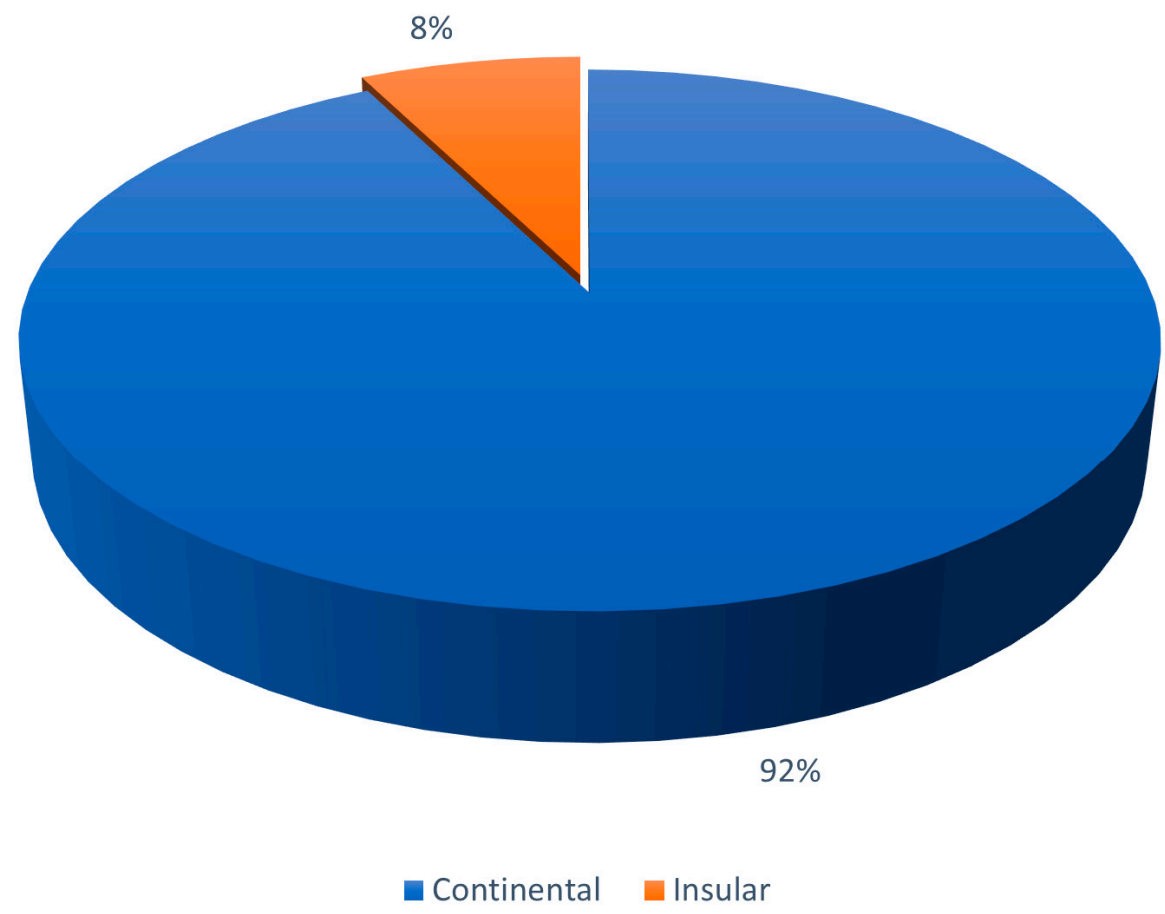

Figure 4. Percentage of all "Extreme rainfall events" articles of Mediterranean bioregion.

Finally, considering only the articles focused on the Mediterranean islands (Figure 5), our results showed that most of these articles had Sicily as study area (31\%; 7 articles), followed by Cyprus (22\%; 5 articles), Sardinia (17\%; 4 articles), Crete and the Balearic Islands (13\%; 3 articles), and Corsica (4\%; 1 articles). Analyzing in depth these articles, we found that the most part dealt with the issue relating to rainfall (10 articles), following global change (5) and floods (4), accordingly the general trend already seen. Among these, only two papers focused on the impacts of these phenomena on vegetation [121,122]. In 
summary, the results relating to the articles on "Extreme rainfall events", at least in the analyzed literature, are largely specific to the geographic areas to which they are addressed, i.e., European countries and specifically those included in the Mediterranean bioregion. However, the low number of articles concerning Mediterranean islands appears to be in contrast with the fact that these territories, in addition to being hotspots of global biodiversity, lie in one of the areas most susceptible to climate change in the world [34], being highly exposed to Medicanes [49].

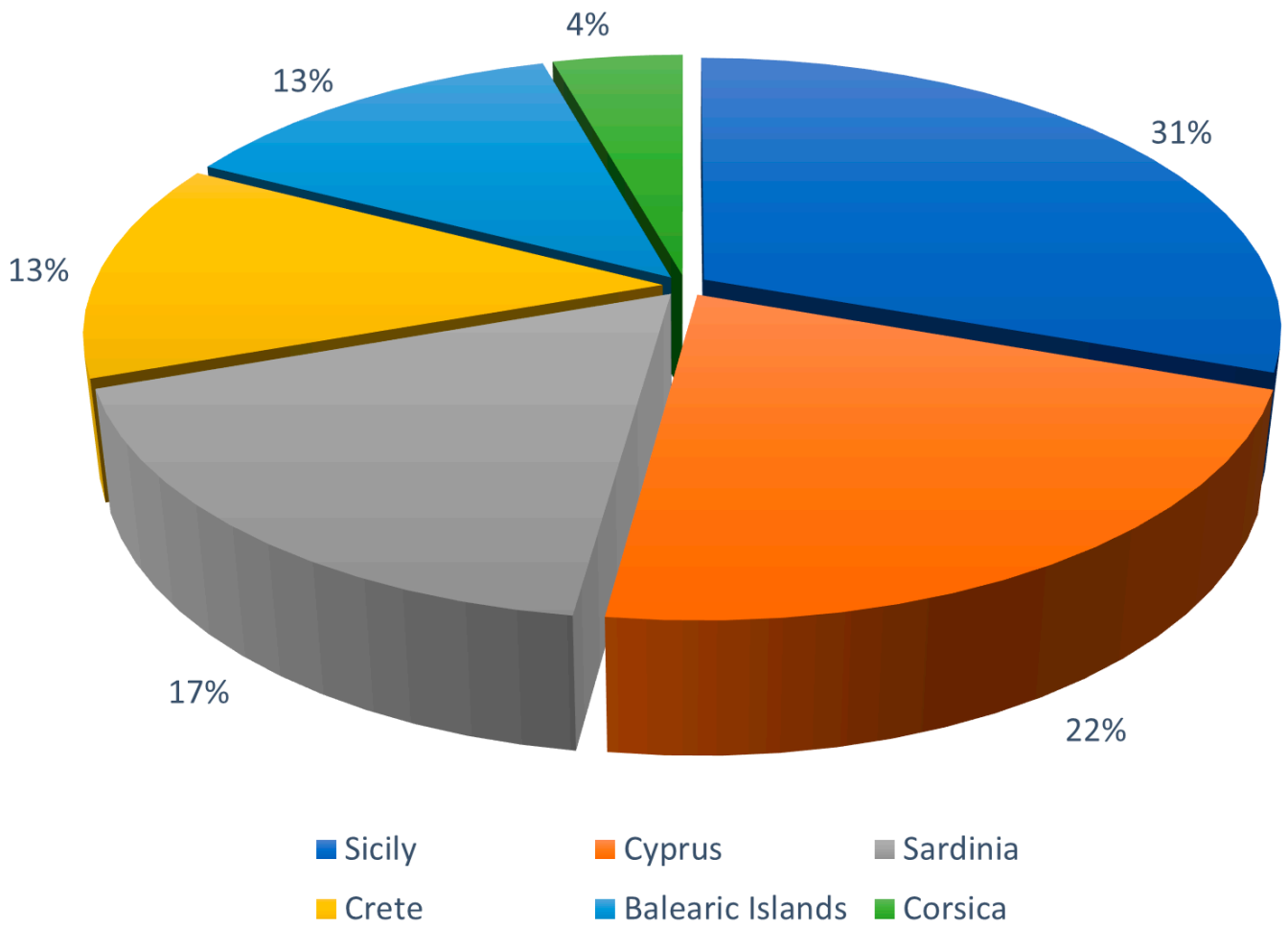

Figure 5. Percentage of all "Extreme rainfall events" articles of Mediterranean bioregion grouped into islands.

Finally, among "Extreme rainfall events", there were only 79 articles referring to the impacts of these phenomena on flora and vegetation, however these represent almost all of the articles (81) concerning the effects of extreme events and global change on vegetation in this review. The number and the temporal trend of articles on "Extreme rainfall and floods" is reported in Figure 6. These articles have increased significantly from 2014 to 2021. Such result confirmed a great interest of scientific community especially during the last decade.

The articles on "Extreme rainfall and floods" analyzed by geographical distribution are shown in Figure 7. In particular, in accordance with "Extreme rainfall events" articles, the study area of most of the articles lay in the Mediterranean bioregion (66\%; 102 articles), followed by the continental $(19 \% ; 30$ articles) and Alpine $(9 \% ; 14$ articles). In addition, there was a percentage of articles with undefined ( $\% \% ; 8$ articles), and extra Europe distribution (1\%; 2 articles).

The focus on the articles with the Mediterranean bioregion area of study (Figure 8) confirmed the results achieved for articles "Extreme rainfall events", with most of them (79\%; 81 articles) relating to the continental region compared to $21 \%$ (21 articles) of the insular region. 


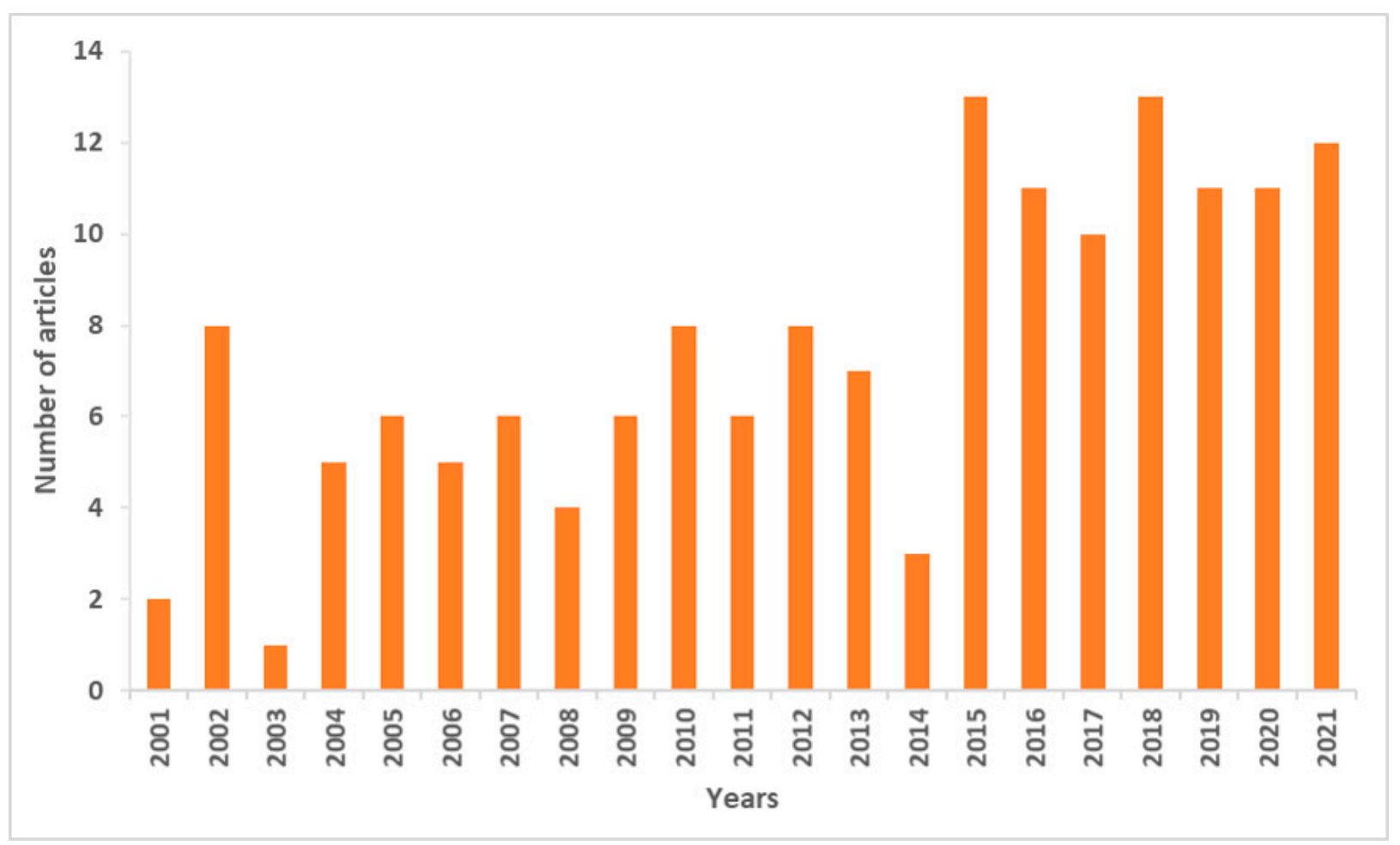

Figure 6. Number of articles on "Extreme rainfall and floods" published from 2001 to 2021 ( $n=156)$.

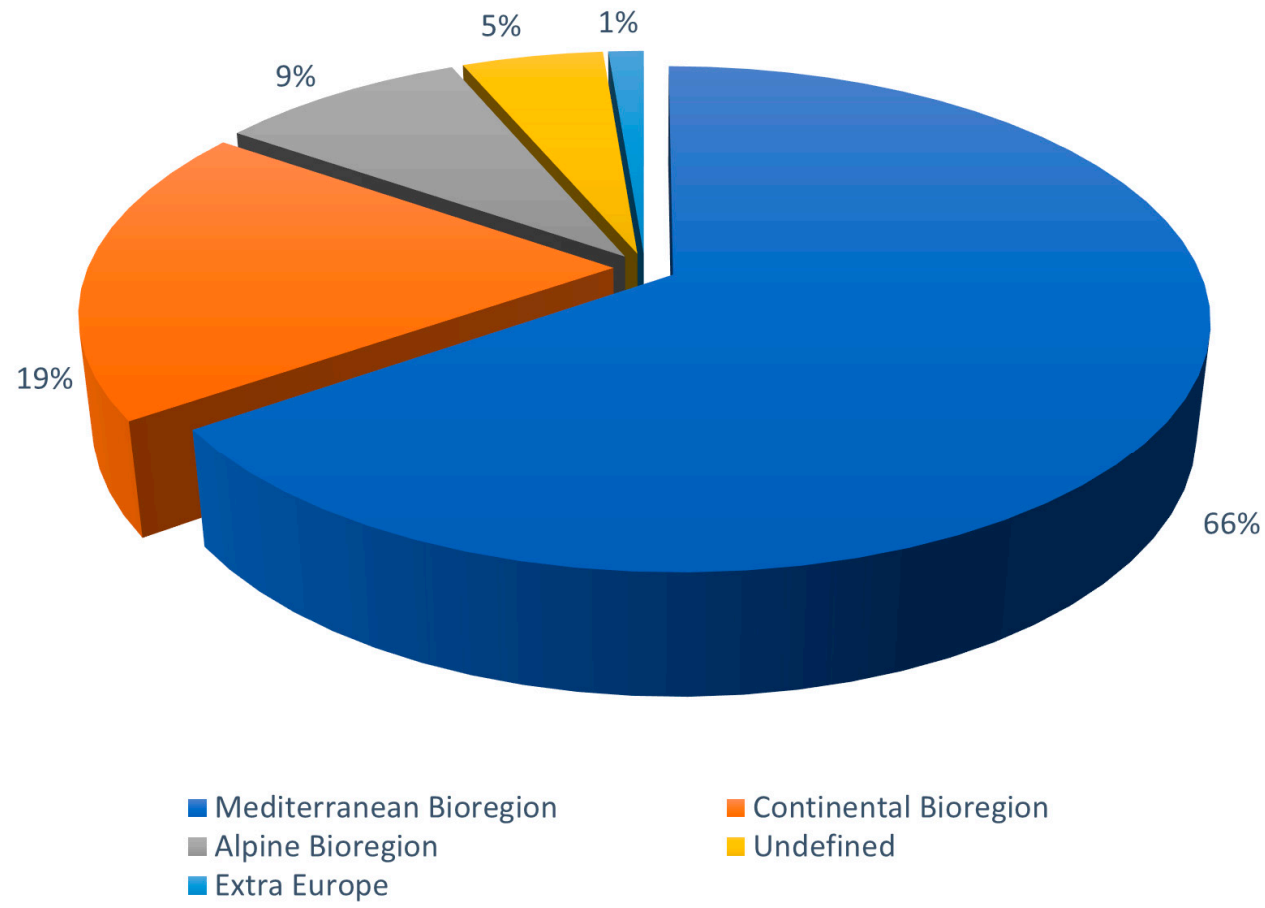

Figure 7. Percentage of all "Extreme rainfall and floods" articles grouped by their geographical distribution. 


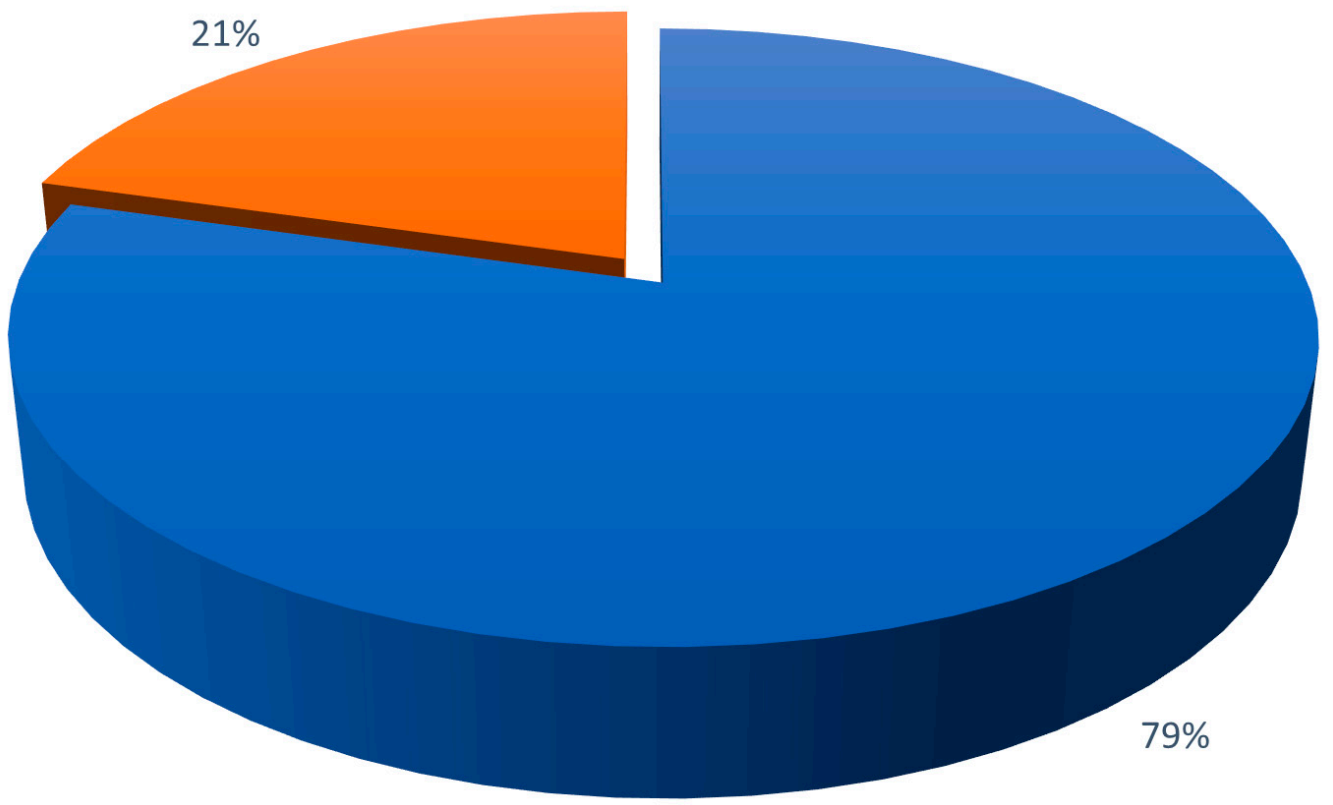

\section{- Continental Insular}

Figure 8. Percentage of all "Extreme rainfall and floods" articles of Mediterranean bioregion.

The analysis of the geographical distribution of the articles on "Extreme rainfall and floods", focused on the Mediterranean insular bioregion (Figure 9), showed that most of the articles had Sicily (76\%; 16 articles) as study area, followed by Sardinia (19\%; 4 articles) and Cyprus $(5 \% ; 1$ articles).

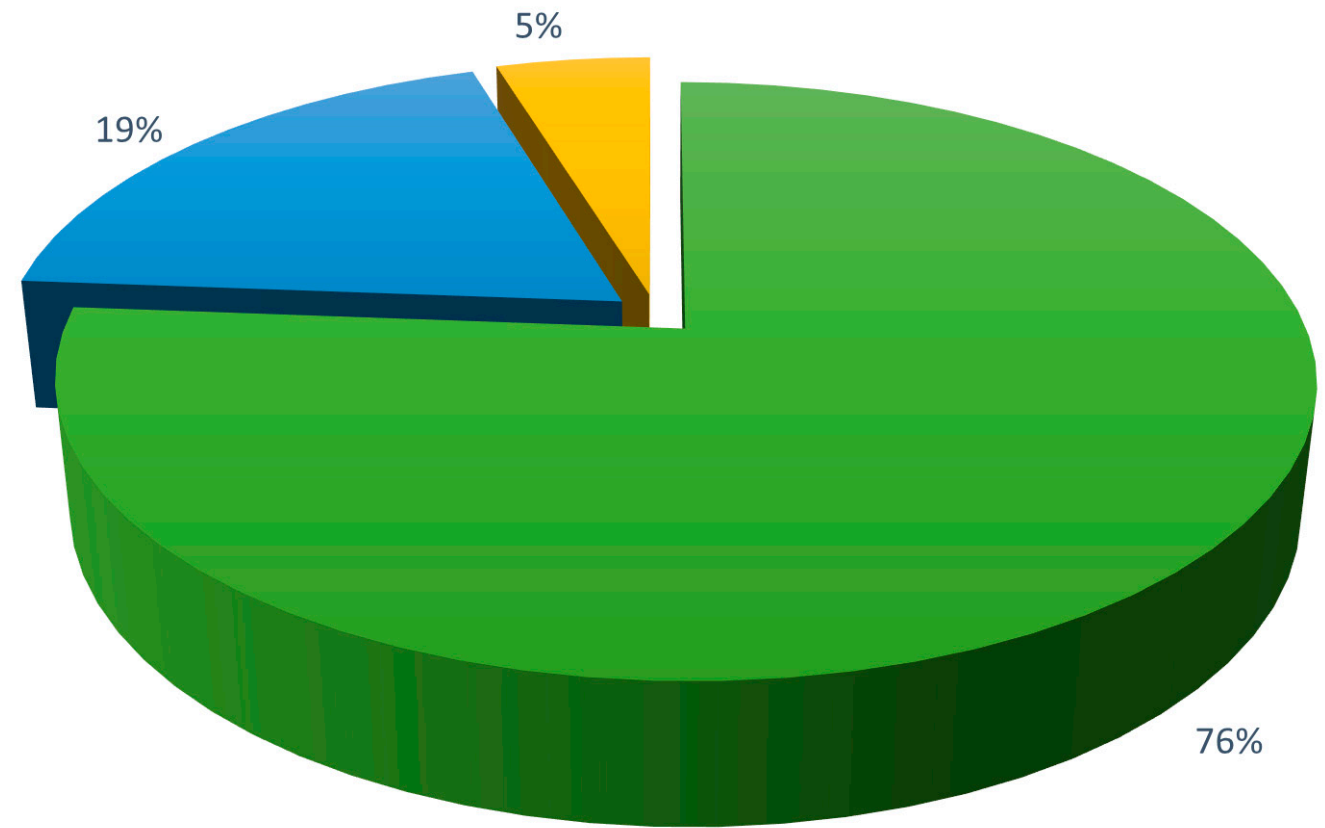

- Sicily a Sardinia $\square$ Cyprus

Figure 9. Percentage of "Extreme rainfall and floods" articles of Mediterranean bioregion grouped into islands. 
Likewise, to what was recorded for "Extreme rainfall events" articles, the most part of papers dealt with the issue relating to precipitation (10 articles), following flood (6) and global change (3).

The results achieved for the articles on "Extreme rainfall and flood" confirmed what has already been recorded for "Extreme rainfall events" articles regarding the geographic distribution, both at the level of bioregions and at the level of islands. As far as articles on "Extreme rainfall and floods" are concerned, unexpectedly, only one was recorded referring to the impacts of these phenomena on flora and vegetation. Specifically, in the study published by Cristiano et al. [123] the performance of CAM (Crassulacean Acid Metabolism) and $\mathrm{C} 3$ vegetation (C3 metabolism, in which the $\mathrm{CO}_{2}$ is fixed into a compound containing three carbon atoms before entering the Calvin cycle of photosynthesis) as green rooftop layers in mitigating extreme rainfall in an urban context was investigated.

These results indicate that, despite the growing interest in this issue, most studies have analyzed these phenomena from the climatic point of view. However, we highlight a lack of specific studies on the effects of climate change from a biological point of view, including flora and vegetation.

\subsection{Extreme Rainfall Events in Mediterranean Basin: Impacts on Vegetation}

Eighty-one articles concerning the effects of extreme events and global change on flora and vegetation have been found. Specifically, the studies concerning the effects of extreme rainfall events in the Mediterranean Basin on vegetation were mainly linked to three types of weather events: "Climate change" (34), "Drought" (18), and "Rainfall" (14). In the articles related to climate change, the effects of global change in general on the growth of Mediterranean forest formations were mainly analyzed and estimated; in particular, for the formations characterized by Quercus, Pinus and Fagus species [124-129]. The articles dealing with the impact of increasing drought on vegetation, on the one hand, concern the assessment of drought, on the other hand, the drought pattern on the Mediterranean formations. The first ones evaluated the impact of drought on the development, composition and productivity of most dominant Mediterranean woodland and shrubland [130-136]; the second ones principally individuated and analyzed the drought patterns and their effects on Mediterranean woodland communities [137-140].

Articles about rainfall effects, for the most part, focused on individuating and describing the impacts of changes in rainfall trends and patterns on productivity, diversity and biological response of Mediterranean woodlands and semiarid plant communities [141-145].

Despite the increase in magnitude and frequency of phenomena such as fires and floods as a result of global change, only a few articles (six and four respectively) have analyzed the impact of these phenomena on vegetation. In the articles related to the fire topic, the main environmental factors that determine severity affecting forest formations located in Mediterranean Basin have been identified and evaluated [146-150]. The studies relating to flood effects on vegetation dealt with flooding risk analysis, assessed on different vegetation types by simulations and models [121,151], by reconstructions of flash floods tree-ring based [152] and by sustainable tools to mitigate urban flood risk [123].

Contrary to our expectations, we found only one article regarding the effects of extreme rainfall events on riparian vegetation. Specifically, Marques et al. [153] evaluated growth trends in riparian tree species, Alnus glutinosa (L.) Gaertn. and Fraxinus angustifolia Vahl, to assess both their resistance and resilience responses to climate changes. In fact, because of their direct dependence on water, riparian ecosystems display a relatively high level of exposure and sensitivity to changes in climatic conditions. In addition, even though flood inundations hit severely and immediately before all the riparian flora and vegetation, no articles have been found in this regard.

Despite this, the lack of studies on these ecosystems seems to be due to the fact that more attention has been paid to the other types of vegetation, in particular, Mediterranean woodland formations (29 articles), shrubland (12 articles) and grasses (11 articles). Among the Mediterranean woodland formations, plant communities characterized by Quercus 
sp. were those mainly studied $[125,129,133,136,140,143,145,154-158]$. The other types of vegetation considered were those including cultivated plants, in particular vine and olive groves [159-166]. These are considered ecosystems with economic and social importance, including their biodiversity and sustainable forest production in these areas; therefore, extremely negative impacts are estimated because of their degradation or loss.

Finally, only three articles concerning alien species resulted among the references found [167-169].

Few articles have been found referring to previous studies regarding the performance of the extreme rainfall events (EREs) on flora and vegetation in the Mediterranean Basin. Among these, articles that analyzed the effects on Mediterranean vegetation in terms of the diversity and resilience to the disturbance due to climate change [170] and the consequences of temperature rising on Mediterranean vegetation, crops and land-use [171]; simulation models were tested to predict changes in Mediterranean plant functional types due to changes in fire recurrence [172] and to predict the response of Mediterranean vegetation characterized by Quercus suber L. to global climate changes, especially fires [173]; the effects of water deficits on the physiology and ecology of plants in Mediterranean-type environments [174]; the impacts of global climate change on Mediterranean agriculture [175].

\subsection{Sardinia as a Study Case}

Mediterranean islands are extremely sensitive and exposed to Medicanes [49] including Sardinia. Therefore, we carried out an in-depth analysis on articles concerning rainfall, Medicanes and floods events that have Sardinia as the study site. In Sardinia, there have been records of rainfall and flood events since 1795. However, there is not a complete literature on these events that occurred in Sardinia, even the extreme ones. In recent decades, especially since 1999, Sardinia has been hit by extreme events with a greater frequency, almost annual/biennial. These data, therefore, seem to confirm that there is a strong link between extreme phenomena and global change. Four major catastrophic events in terms of rainfall, flooding and landslides that affected one or more Sardinian areas in this period of time were recorded:

- $\quad$ October 2008: flood in Capoterra (South Sardinia), which affected the Gutturu Mannu River basin, Rio S. Girolamo and Rio Masone Ollastu, as well as Poggio dei Pini village (Capoterra municipality) and the city of Cagliari.

- November 2013: flood in Olbia (North-Western Sardinia) associated with an extratropical cyclone in the western Mediterranean Basin, called "Cyclone Cleopatra".

- October 2018: flood in Capoterra (South Sardinia), the cities of Cagliari and Capoterra were hit by torrential rains that caused a flood of Santa Lucia River; the same Mediterranean perturbation also affected some localities in the Sarrabus region.

- October 2020: flood in Bitti (North-Eastern Sardinia) caused by a large cyclone that brought heavy rainfall along the Eastern part of the Sardinia region.

Despite all these extreme events, it is noteworthy that the data available on these events come mainly from websites (such as Sardegna Clima Onlus, https://sardegna-clima.it/; accessed on 15 December 2021), newspaper articles, and degree theses, while only a few research papers relating to specific extreme weather events have been published. Specifically, such articles concerned the flood of Villagrande Strisaili (Ogliastra) which occurred in 2004 [176,177], the Capoterra flood in 2008 [178,179] and cyclone Cleopatra in 2013 [179-183].

Our bibliographic overview has shown that the number of published papers related to these phenomena is very low. From analysis of articles regarding extreme rainfall events in the Mediterranean Basin with Sardinia as a study area, a total of seven articles were found. Specifically, three of them were climate studies: the first focused on the analysis of the spatial and temporal variability precipitation in Sardinia [184], the second analyzed heavy rainfall events occurred in the Province of Ogliastra in order to improve land use planning and the application of suitable prevention systems [185], and the third assessed the impacts of an extreme flood on the natural and geomorphological heritage in the coastal area [176]. 
The other four studies concerned the effects of extreme rainfall events on different types of environments and plant organisms: phytoplankton in Cabras Lagoon [122]; Mediterranean holm oak (Quercus ilex L.) in the public forest of Marganai [157]; CAM and C3 vegetation in the previously mentioned study published by Cristiano et al. [123]; and assessment of responses of soil in agricultural land-use types in a river basin [121].

\section{Conclusions}

This review summarizes what has been provided so far in the literature on the effects of extreme rainfall events on the flora and vegetation in the Mediterranean Basin, supplying an in-depth picture of the literature published on this challenging theme.

Taking into account our results, we found that most of the articles published on the effects of extreme rainfall events in the Mediterranean Basin in the last twenty years have focused on the impacts of these phenomena from the climate point of view, in particular, those concerning "Rain/Precipitation", "Global/Climate change" and "Flood". Conversely, a limited number of studies have been detected on the effects of extreme events and global change on vegetation. Among the latter, the main types of vegetation investigated were Mediterranean woodland, shrubland, and grasses formations, followed by cultivated plants, in particular vine and olive groves. However, contrary to expectations, we found only one article regarding the effects on riparian vegetation.

In fact, although water and riparian ecosystems show a high level of exposure and sensitivity to changes in climatic conditions, the greatest interest of the scientific community has been directed to the other type of vegetation more common in the Mediterranean Basin and with economic and social importance.

From the point of their geographical distribution, most of the articles related to "Extreme rainfall events" and "Extreme rainfall and floods" referred to the Mediterranean bioregion, of which only a small part focused on the insular Mediterranean bioregion and regarding the same issues already faced for the articles in general. The same topics were recorded for the articles with Sardinian case study, which indicated an increase in extreme events with a greater frequency, almost annual/biennial, in the last two decades.

It is worth highlighting the lack of studies regarding Mediterranean islands, despite the islands' great value as hotspots of global biodiversity and being in one of the territories most susceptible to climate change in the world. Therefore, these results suggest that further specific studies are needed on the effects of climate change in the Mediterranean Basin, including those concerning the impacts on flora and vegetation and specifically at the islands level. Our analysis highlighted the dramatic lack of studies on the effects of extreme rainfall events on riparian flora and vegetation, which are the first to be abruptly affected by these phenomena. This review constitutes a call for researchers to explore this challenging theme now that extreme phenomena have become extremely recurrent, especially in the Mediterranean Basin.

Supplementary Materials: The following supporting information can be downloaded at: https: / / www.mdpi.com/article/10.3390/w14050817/s1, Supplementary S1: Extreme rainfall events; Supplementary S2: Extreme rainfall and floods.

Author Contributions: Conceptualization, M.S.P., M.C.L. and G.F.; methodology, M.S.P., M.C.L. and G.F.; formal analysis, M.S.P. and G.F.; investigation, M.S.P. and M.C.L.; data curation, M.S.P., M.C.L., G.C. and G.F.; writing—original draft preparation, M.S.P. and M.C.L.; writing—review and editing, M.S.P., G.C. and G.F.; visualization, M.S.P., M.C.L., G.C. and G.F.; supervision, G.F. All authors have read and agreed to the published version of the manuscript.

Funding: This research received no external funding.

Data Availability Statement: Not applicable.

Acknowledgments: This study is part of the research scholarship programs of M.S.P. and G.C. and supported by the project "Effects of climate environmental shifts on species, communities and ecosystems" funded by Fondazione di Sardegna (2018). 
Conflicts of Interest: The authors declare no conflict of interest.

\section{References}

1. World Meteorological Organization (WMO). Provisional Report on the State of the Global Climate-In Statement on the State of the Global Climate. Available online: https:/ /library.wmo.int/index.php?lvl=notice_display\&id=21804\#.YX-1-J7MI2z (accessed on 25 December 2021).

2. IPCC. Global Warming of $1.5^{\circ} \mathrm{C}$. In An IPCC Special Report on the Impacts of Global Warming of $1.5^{\circ} \mathrm{C}$ above Pre-Industrial Levels and Related Global Greenhouse Gas Emission Pathways, in the Context of Strengthening the Global Response to the Threat of Climate Change, Sustainable Development, and Efforts to Eradicate Poverty; Masson-Delmotte, V., Zhai, P., Pörtner, H.O., Roberts, D., Skea, J., Shukla, P.R., Pirani, A., Moufouma-Okia, W., Péan, C., Pidcock, R., et al., Eds.; IPCC: Geneva, Switzerland, 2018; p. 616.

3. IPCC. Climate Change 2014: Synthesis Report. In Contribution of Working Groups I, II and III to the Fifth Assessment Report of the Intergovernmental Panel on Climate Change; Pachauri, R.K., Meyer, L.A., Eds.; IPCC: Geneva, Switzerland, $2014 ;$ p. 151.

4. Hegerl, G.C.; Brönnimann, S.; Cowan, T.; Friedman, A.R.; Hawkins, E.; Iles, C.; Müller, W.; Schurer, A.; Undorf, S. Causes of climate change over the historical record. Environ. Res. Lett. 2019, 14, 123006. [CrossRef]

5. Fawzy, S.; Osman, A.I.; Doran, J.; Rooney, D.W. Strategies for mitigation of climate change: A review. Environ. Chem. Lett. 2020, 18, 2069-2094. [CrossRef]

6. Purkey, S.G.; Johnson, G.C. Warming of Global Abyssal and Deep Southern Ocean Waters between the 1990s and 2000s: Contributions to Global Heat and Sea Level Rise Budgets. J. Clim. 2010, 23, 6336-6351. [CrossRef]

7. $\quad$ von Schuckmann, K.; Cheng, L.; Palmer, M.D.; Hansen, J.; Tassone, C.; Aich, V.; Adusumilli, S.; Beltrami, H.; Boyer, T.; CuestaValero, F.J.; et al. Heat stored in the Earth system: Where does the energy go? Earth Syst. Sci. Data 2020, 12, 2013-2041. [CrossRef]

8. García-Monteiro, S.; Sobrino, J.; Julien, Y.; Sòria, G.; Skokovic, D. Surface Temperature trends in the Mediterranean Sea from MODIS data during years 2003-2019. Reg. Stud. Mar. Sci. 2022, 49, 102086. [CrossRef]

9. Doney, S.C.; Busch, D.S.; Cooley, S.R.; Kroeker, K.J. The Impacts of Ocean Acidification on Marine Ecosystems and Reliant Human Communities. Annu. Rev. Environ. Resour. 2020, 45, 83-112. [CrossRef]

10. European Environment Agency (EEA). Trends and Drivers of EU Greenhouse Gas Emissions. Available online: https://www.eea europa.eu/publications/trends-and-drivers-of-eu-ghg (accessed on 20 September 2021).

11. Doney, S.C.; Fabry, V.J.; Feely, R.A.; Kleypas, J.A. Ocean Acidification: The Other CO2 Problem. Annu. Rev. Mar. Sci. 2009, 1, 169-192. [CrossRef]

12. Hall-Spencer, J.M.; Harvey, B.P. Ocean acidification impacts on coastal ecosystem services due to habitat degradation. Emerg. Top. Life Sci. 2019, 3, 197-206. [CrossRef]

13. Rogelj, J.; Popp, A.; Calvin, K.V.; Luderer, G.; Emmerling, J.; Gernaat, D.; Fujimori, S.; Strefler, J.; Hasegawa, T.; Marangoni, G.; et al. Scenarios towards limiting global mean temperature increase below $1.5^{\circ} \mathrm{C}$. Nat. Clim. Chang. 2018, 8, 325-332. [CrossRef]

14. United Nations Environment Programme (UNEP). Emissions Gap Report 2020. Available online: https://www.unep.org/ emissions-gap-report-2020 (accessed on 20 September 2021).

15. European Environment Agency (EEA). Ocean Acidification. Available online: https://www.eea.europa.eu/data-and-maps/ indicators/ocean-acidification-4/assessment (accessed on 20 September 2021).

16. European Environment Agency (EEA). Annual European Union Greenhouse Gas Inventory 1990-2018 and Inventory Report 2020. Available online: https:/ / www.eea.europa.eu/publications/european-union-greenhouse-gas-inventory-2020 (accessed on 25 September 2021).

17. IPCC. Climate Change 2013: The Physical Science Basis. In Contribution of Working Group I to the Fifth Assessment Report of the Intergovernmental Panel on Climate Change; Stocker, T.F., Qin, D., Plattner, G.K., Tignor, M.M.B., Allen, S.K., Boschung, J., Nauels, A., Xia, Y., Bex, V., Midgley, P.M., Eds.; Cambridge University Press: Cambridge, UK; New York, NY, USA, 2013 ; p. 1535.

18. Easterling, D.R.; Meehl, G.A.; Parmesan, C.; Changnon, S.A.; Karl, T.R.; Mearns, L.O. Climate Extremes: Observations, Modeling, and Impacts. Science 2000, 289, 2068-2074. [CrossRef]

19. Jentsch, A.; Beierkuhnlein, C. Research frontiers in climate change: Effects of extreme meteorological events on ecosystems. Comptes Rendus Geosci. 2008, 340, 621-628. [CrossRef]

20. Depietri, Y.; Renaud, F.G.; Kallis, G. Heat waves and floods in urban areas: A policy-oriented review of ecosystem services. Sustain. Sci. 2012, 7, 95-107. [CrossRef]

21. Lloret, F.; Escudero, A.; Iriondo, J.M.; Martínez-Vilalta, J.; Valladares, F. Extreme climatic events and vegetation: The role of stabilizing processes. Glob. Chang. Biol. 2012, 18, 797-805. [CrossRef]

22. Grimm, N.B.; Chapin, F.S., III; Bierwagen, B.; Gonzalez, P.; Groffman, P.M.; Luo, Y.; Melton, F.; Nadelhoffer, K.; Pairis, A.; Raymond, P.A.; et al. The impacts of climate change on ecosystem structure and function. Front. Ecol. Environ. 2013, 11, 474-482. [CrossRef]

23. Black, R.; Arnell, N.W.; Adger, W.N.; Thomas, D.; Geddes, A. Migration, immobility and displacement outcomes following extreme events. Environ. Sci. Policy 2013, 27, 32-43. [CrossRef]

24. Heim, R.R. An overview of weather and climate extremes-Products and trends. Weather Clim. Extrem. 2015, 10, 1-9. [CrossRef] 
25. Thomas, K.; Hardy, R.D.; Lazrus, H.; Mendez, M.; Orlove, B.; Rivera-Collazo, I.; Roberts, J.T.; Rockman, M.; Warner, B.P.; Winthrop, R. Explaining differential vulnerability to climate change: A social science review. Wiley Interdiscip. Rev. Clim. Chang. 2019, 10, 565. [CrossRef]

26. Korell, L.; Auge, H.; Chase, J.M.; Harpole, W.S.; Knight, T.M. Responses of plant diversity to precipitation change are strongest at local spatial scales and in drylands. Nat. Commun. 2021, 12, 1-7. [CrossRef]

27. IPCC. Climate Change 2007: Impacts, Adaptation and Vulnerability. In Contribution of Working Group II to the Fourth Assessment Report of the Intergovernmental Panel on Climate Change; Parry, M.L., Canziani, O.F., Palutikof, J.P., van der Linden, P.J., Hanson, C.E., Eds.; Cambridge University Press: Cambridge, UK, 2007; p. 976.

28. Cayan, D.C.; Maurer, E.; Dettinger, M.D.; Tyree, M.; Hayhoe, K.; Bonfils, C.; Duffy, P.; Santer, B. Climate Scenarios for California. California Climate Change Center, California Energy Commission; Report CEC-500-2005-203-SD; UC Berkeley: Sacramento, CA, USA, 2006; p. 47.

29. Christensen, J.H.; Hewitson, B.; Busuioc, A.; Chen, A.; Gao, X.; Held, I.; Jones, R.; Kolli, R.K.; Kwon, W.-T.; Laprise, R.; et al. Regional Climate Projections. In Climate Change 2007: The Physical Science Basis. Contribution of Working Group I to the Fourth Assessment Report of the Intergovernmental Panel on Climate Change; Solomon, S., Qin, D., Manning, M., Chen, Z., Marquis, M., Averyt, K.B., Tignor, M., Miller, H.L., Eds.; Cambridge University Press: Cambridge, UK; New York, NY, USA, 2007 ; pp. 847-890.

30. Giorgi, F.; Lionello, P. Climate change projections for the Mediterranean region. Glob. Planet. Chang. 2008, 63, 90-104. [CrossRef]

31. Giannakopoulos, C.; Le Sager, P.; Bindi, M.; Moriondo, M.; Kostopoulou, E.; Goodess, C.M. Climatic changes and associated impacts in the Mediterranean resulting from a $2{ }^{\circ} \mathrm{C}$ global warming. Glob. Planet. Chang. 2009, 68, 209-224. [CrossRef]

32. Cardell, M.F.; Amengual, A.; Romero, R.; Ramis, C. Future extremes of temperature and precipitation in Europe derived from a combination of dynamical and statistical approaches. Int. J. Climatol. 2020, 40, 4800-4827. [CrossRef]

33. Moatti, J.-P.; Thiébault, S. The Mediterranean Region under Climate Change: A Scientific Update; AllEnvi: Marseille, France, 2016.

34. Vogiatzakis, I.N.; Mannion, A.M.; Sarris, D. Mediterranean island biodiversity and climate change: The last 10,000 years and the future. Biodivers. Conserv. 2016, 25, 2597-2627. [CrossRef]

35. Ducrocq, V.; Drobinski, P.; Gualdi, S.; Raimbault, P. The water cycle in the Mediterranean. In The Mediterranean Region under Climate Change: A Scientific Update; Moatti, J., Thiébault, S., Eds.; IRD Éditions: Marseille, France, 2016; pp. 73-81.

36. Mariotti, A.; Pan, Y.; Zeng, N.; Alessandri, A. Long-term climate change in the Mediterranean region in the midst of decadal variability. Clim. Dyn. 2015, 44, 1437-1456. [CrossRef]

37. Michaelides, S.; Karacostas, T.; Sánchez, J.L.; Retalis, A.; Pytharoulis, I.; Homar, V.; Romero, R.; Zanis, P.; Giannakopoulos, C.; Bühl, J.; et al. Reviews and perspectives of high impact atmospheric processes in the Mediterranean. Atmos. Res. 2018, $208,4-44$. [CrossRef]

38. Kostopoulou, E.; Jones, P.D. Assessment of climate extremes in the Eastern Mediterranean. Meteorol. Atmos. Phys. 2005, 89, 69-85. [CrossRef]

39. Cherif, S.; Doblas-Miranda, E.; Lionello, P.; Borrego, C.; Giorgi, F.; Iglesias, A.; Jebari, S.; Mahmoudi, E.; Moriondo, M.; Pringault, O.; et al. Drivers of change. In Climate and Environmental Change in the Mediterranean Basin-Current Situation and Risks for the Future. First Mediterranean Assessment Report; Cramer, W., Guiot, J., Marini, K., Eds.; Union for the Mediterranean, Plan Bleu, UNEP/MAP: Marseille, France, 2020; pp. 59-180.

40. Lionello, P.; Scarascia, L. The relation of climate extremes with global warming in the Mediterranean region and its north versus south contrast. Reg. Environ. Chang. 2020, 20, 31. [CrossRef]

41. Rädler, A.T.; Groenemeijer, P.H.; Faust, E.; Sausen, R.; Púčik, T. Frequency of severe thunderstorms across Europe expected to increase in the 21st century due to rising instability. NPJ Clim. Atmos. Sci. 2019, 2, 30. [CrossRef]

42. Miglietta, M.M.; Rotunno, R. Development mechanisms for Mediterranean tropical-like cyclones (medicanes). Q. J. R. Meteorol. Soc. 2019, 145, 1444-1460. [CrossRef]

43. Mastrantonas, N.; Herrera-Lormendez, P.; Magnusson, L.; Pappenberger, F.; Matschullat, J. Extreme precipitation events in the Mediterranean: Spatiotemporal characteristics and connection to large-scale atmospheric flow patterns. Int. J. Climatol. 2021, 41, 2710-2728. [CrossRef]

44. Patlakas, P.; Stathopoulos, C.; Tsalis, C.; Kallos, G. Wind and wave extremes associated with tropical-like cyclones in the Mediterranean basin. Int. J. Climatol. 2021, 41, 1623-1644. [CrossRef]

45. Cavicchia, L.; von Storch, H.; Gualdi, S. A long-term climatology of medicanes. Clim. Dyn. 2014, 43, 1183-1195. [CrossRef]

46. Emanuel, K. Genesis and maintenance of "Mediterranean hurricanes". Adv. Geosci. 2005, 2, 217-220. [CrossRef]

47. Ragone, F.; Mariotti, M.; Parodi, A.; von Hardenberg, J.; Pasquero, C. A Climatological Study of Western Mediterranean Medicanes in Numerical Simulations with Explicit and Parameterized Convection. Atmosphere 2018, 9, 397. [CrossRef]

48. Zhang, W.; Villarini, G.; Scoccimarro, E.; Napolitano, F. Examining the precipitation associated with medicanes in the highresolution ERA-5 reanalysis data. Int. J. Climatol. 2021, 41, 126-132. [CrossRef]

49. Romero, R.; Emanuel, K. Medicane risk in a changing climate. J. Geophys. Res-Atmos. 2013, 118, 5992-6001. [CrossRef]

50. Romero, R.; Emanuel, K. Climate change and hurricane-like extratropical cyclones: Projections for North Atlantic polar lows and medicanes based on CMIP5 models. J. Clim. 2017, 30, 279-299. [CrossRef]

51. Cavicchia, L.; von Storch, H.; Gualdi, S. Mediterranean Tropical-Like Cyclones in Present and Future Climate. J. Clim. 2014, 27, 7493-7501. [CrossRef] 
52. Dayan, U.; Nissen, K.; Ulbrich, U. Review Article: Atmospheric conditions inducing extreme precipitation over the eastern and western Mediterranean. Nat. Hazards Earth Syst. Sci. 2015, 15, 2525-2544. [CrossRef]

53. Cioni, G.; Cerrai, D.; Klocke, D. Investigating the predictability of a Mediterranean tropical-like cyclone using a storm-resolving model. Q. J. R. Meteorol. Soc. 2018, 144, 1598-1610. [CrossRef]

54. Flaounas, E.; Kotroni, V.; Lagouvardos, K.; Gray, S.L.; Rysman, J.-F.; Claud, C. Heavy rainfall in Mediterranean cyclones. Part I: Contribution of deep convection and warm conveyor belt. Clim. Dyn. 2018, 50, 2935-2949. [CrossRef]

55. González-Alemán, J.J.; Pascale, S.; Gutierrez-Fernandez, J.; Murakami, H.; Gaertner, M.A.; Vecchi, G.A. Potential increase in hazard from Mediterranean hurricane activity with global warming. Geophys. Res. Lett. 2019, 46, 1754-1764. [CrossRef]

56. Miglietta, M.M. Mediterranean Tropical-Like Cyclones (Medicanes). Atmosphere 2019, 10, 206-210. [CrossRef]

57. Pravia-Sarabia, E.; Gómez-Navarro, J.J.; Jiménez-Guerrero, P.; Montávez, J.P. TITAM (v1.0): The Time-Independent Tracking Algorithm for Medicanes. Geosci. Model Dev. 2020, 13, 6051-6075. [CrossRef]

58. de la Vara, A.; Gutiérrez-Fernández, J.; González-Alemán, J.J.; Gaertner, M.A. Characterization of medicanes with a minimal number of geopotential levels. Int. J. Climatol. 2021, 4, 3300-3316. [CrossRef]

59. Miglietta, M.M.; Carnevale, D.; Levizzani, V.; Rotunno, R. Role of moist and dry air advection in the development of Mediterranean tropical-like cyclones (medicanes). Q. J. R. Meteorol. Soc. 2021, 147, 876-899. [CrossRef]

60. Claud, C.; Alhammoud, B.; Funatsu, B.M.; Chaboureau, J.-P. Mediterranean hurricanes: Large-scale environment and convective and precipitating areas from satellite microwave observations. Nat. Hazards Earth Syst. Sci. 2010, 10, 2199-2213. [CrossRef]

61. Tous, M.; Romero, R. Meteorological environments associated with medicane development. Int. J. Climatol. 2013, 33, 1-14. [CrossRef]

62. Gaertner, M.Á.; González-Alemán, J.J.; Romera, R.; Domínguez, M.; Gil, V.; Sánchez, E.; Gallardo, C.; Miglietta, M.M.; Walsh, K.J.E.; Sein, D.V.; et al. Simulation of Medicanes over the Mediterranean Sea in a regional climate model ensemble: Impact of ocean-atmosphere coupling and increased resolution. Clim. Dyn. 2018, 51, 1041-1057. [CrossRef]

63. Akhtar, N.; Brauch, J.; Dobler, A.; Béranger, K.; Ahrens, B. Medicanes in an ocean-atmosphere coupled regional climate model. Nat. Hazards Earth Syst. Sci. 2014, 14, 2189-2201. [CrossRef]

64. Miglietta, M.M.; Cerrai, D.; Laviola, S.; Cattani, E.; Levizzani, V. Potential vorticity patterns in Mediterranean "hurricanes". Geophys. Res. Lett. 2017, 44, 2537-2545. [CrossRef]

65. Miglietta, M.M.; Laviola, S.; Malvaldi, A.; Conte, D.; Levizzani, V.; Price, C. Analysis of tropical-like cyclones over the Mediterranean Sea through a combined modelling and satellite approach. Geophys. Res. Lett. 2013, 40, 2400-2405. [CrossRef]

66. Davolio, S.; Della Fera, S.; Laviola, S.; Miglietta, M.M.; Levizzani, V. Heavy Precipitation over Italy from the Mediterranean Storm "Vaia" in October 2018: Assessing the Role of an Atmospheric River. Mon. Weather Rev. 2020, 148, 3571-3588. [CrossRef]

67. Bouin, M.-N.; Lebeaupin Brossier, C. Surface processes in the 7 November 2014 medicane from air-sea coupled high-resolution numerical modelling. Atmos. Chem. Phys. 2020, 20, 6861-6881. [CrossRef]

68. Lugon, J., Jr.; Juliano, M.M.; Kyriakides, I.; Yamasaki, E.N.; Rodrigues, P.P.G.W.; Silva Neto, A.J. Environmental hydrodynamic modeling applied to extreme events in Caribbean and Mediterranean countries. Desalin. Water Treat. 2020, 194, 315-323. [CrossRef]

69. Nastos, P.T.; Papadimou, K.K.; Matsangouras, I.T. Mediterranean tropical-like cyclones: Impacts and composite daily means and anomalies of synoptic patterns. Atmos. Res. 2018, 208, 156-166. [CrossRef]

70. Romera, R.; Gaertner, M.A.; Sánchez, E.; Domínguez, M.; González-Alemán, J.J.; Miglietta, M.M. Climate change projections of Medicanes with a large multi-model ensemble of regional climate models. Glob. Planet. Chang. 2017, 151, 134-143. [CrossRef]

71. Moreno, J.M.; Álvarez Cobelas, M.; Benito, G.; Catalán, J.; Ramos, M.; Rosa, D.D.L.; Valladares Ros, F.; Zazo, C. Principales Conclusiones de la Evaluación Preliminar de los Impactos en España por Efecto del Cambio Climático; Ministerio de Medio Ambiente: Madrid, Spain, 2005.

72. Cantonati, M.; Poikane, S.; Pringle, C.M.; Stevens, L.E.; Turak, E.; Heino, J.; Richardson, J.S.; Bolpagni, R.; Borrini, A.; Cid, N.; et al. Characteristics, Main Impacts, and Stewardship of Natural and Artificial Freshwater Environments: Consequences for Biodiversity Conservation. Water 2020, 12, 260. [CrossRef]

73. Maasri, A.; Jähnig, S.; Adamescu, M.; Adrian, R.; Baigun, C.; Baird, D.; Batista-Morales, A.; Bonada, N.; Brown, L.; Cai, Q.; et al. A global agenda for advancing freshwater biodiversity research. Ecol. Lett. 2021, 25, 255-263. [CrossRef]

74. Naiman, R.J.; Décamps, H.; McClain, M.E. Riparia: Ecology, Conservation, and Management of Streamside Communities, 1st ed.; Elsevier Academic Press: San Diego, CA, USA, 2005; p. 430.

75. Zogaris, S.; Chatzinikolaou, Y.; Diplopoulos, P. Riparian woodland flora in upland rivers of Western Greece. Mediterr. Mar. Sci. 2008, 9, 87-102. [CrossRef]

76. Naiman, R.J.; Décamps, H. The ecology of interfaces-riparian zones. Annu. Rev. Ecol. Syst. 1997, 28, 621-658. [CrossRef]

77. Naiman, R.J.; Décamps, H.; Pollock, M. The role of riparian corridors in maintaining regional biodiversity. Ecol. Appl. 1993, 3 , 209-212. [CrossRef] [PubMed]

78. Gregory, S.V.; Swanson, F.J.; McKee, W.A.; Cummins, K.W. An ecosystem prospective of riparian zones. BioScience 1991, 41, 540-551. [CrossRef]

79. Tang, S.M.; Montgomery, D.R. Riparian buffers and potentially unstable ground. Environ. Manag. 1995, 19, 741. [CrossRef]

80. Barling, R.D.; Moore, I.D. Role of buffer strips in management of waterway pollution: A review. Environ. Manag. 1994, 18, 543-558. [CrossRef] 
81. Hood, G.W.; Naiman, R.J. Vulnerability of riparian zones to evasion by exotic vascular plants. Plant Ecol. 2000, 148, 105-114. [CrossRef]

82. Ward, J.V. Riverine-wetland interactions. In Freshwater Wetlands and Wildlife; Sharitz, R.R., Gibbons, J.W., Eds.; DOE Symp: Oak Ridge, TN, USA, 1989; pp. 385-400.

83. Mikulová, K.; Jarolímek, I.; Šibík, J.; Bacigál, T.; Šibíková, M. Long-Term Changes of Softwood Floodplain Forests-Did the Disappearance of Wet Vegetation Accelerate the Invasion Process? Forests 2020, 11, 1218. [CrossRef]

84. Décamps, H. River margins and environmental change. Ecol. Appl. 1993, 3, 441-445. [CrossRef]

85. Naiman, R.J.; Décamps, H.; Pastor, J.; Johnston, C.A. The potential importance of boundaries to fluvial ecosystems. J. N. Am. Benthol. Soc. 1988, 7, 289-306. [CrossRef]

86. Nucci, A.; Angiolini, C.; Landi, M.; Bacchetta, G. Regional and local patterns of riparian flora: Comparison between insular and continental mediterranean rivers. Ecoscience 2012, 19, 213-224. [CrossRef]

87. Bolpagni, R.; Lastrucci, L.; Brundu, G.; Hussner, A. Multiple roles of alien Plants in aquatic ecosystems: From processes to modelling. Front. Plant Sci. 2020, 11, 1299. [CrossRef]

88. Gentili, R.; Armiraglio, S.; Rossi, G.; Sgorbati, S.; Baroni, C. Floristic patterns, ecological gradients and biodiversity in the composite channels (Central Alps, Italy). Flora 2010, 205, 388-398. [CrossRef]

89. Pettit, N.E.; Froend, R.H.; Davis, P.M. Identifying the natural flow regime and the relationship with riparian vegetation for two contrasting western Australian rivers. Regul. River. 2001, 17, 201-215. [CrossRef]

90. Ferreira, M.T.; Aguiar, F.C. Riparian and aquatic vegetation in Mediterranean-type streams (western Iberia). Limnetica 2006, 25, 411-424. [CrossRef]

91. Mejías, J.A.; Arroyo, J.; Marañón, T. Ecology and biogeography of plant communities associated with the post Plio-Pleistocene relict Rhododendron ponticum subsp. baeticum in southern Spain. J. Biogeogr. 2006, 34, 456-472. [CrossRef]

92. Aguiar, F.C.; Ferreira, M.T. Human-disturbed landscapes: Effects on composition and integrity of riparian woody vegetation in the Tagus River basin, Portugal. Environ. Conserv. 2005, 32, 30-41. [CrossRef]

93. Cooper, S.D.; Page, H.M.; Wiseman, S.W.; Klose, K.; Bennett, D.; Even, T.; Sadro, S.; Nelson, C.E.; Dudley, T.L. Physicochemical and biological responses of streams to wildfire severity in riparian zones. Freshwater Biol. 2015, 60, 2600-2619. [CrossRef]

94. Filipe, A.F.; Lawrence, J.E.; Bonada, N. Vulnerability of stream biota to climate change in mediterranean climate regions: A synthesis of ecological responses and conservation challenges. Hydrobiologia 2013, 719, 331-351. [CrossRef]

95. Hershkovitz, Y.; Gasith, A. Resistance, resilience, and community dynamics in mediterranean-climate streams. Hydrobiologia 2013, 719, 59-75. [CrossRef]

96. Robson, B.J.; Chester, E.T.; Mitchell, B.D.; Matthews, T.G. Disturbance and the role of refuges in mediterranean climate streams. Hydrobiologia 2013, 719, 77-91. [CrossRef]

97. Stella, J.C.; Rodríguez-González, P.M.; Dufour, S.; Bendix, J. Riparian vegetation research in Mediterranean-climate regions: Common patterns, ecological processes, and considerations for management. Hydrobiologia 2013, 719, 291-315. [CrossRef]

98. Lozanovska, I.; Bejarano, M.D.; Martins, M.J.; Nilsson, C.; Ferreira, M.T.; Aguiar, F.C. Functional Diversity of Riparian Woody Vegetation Is Less Affected by River Regulation in the Mediterranean Than Boreal Region. Front. Plant Sci. 2020, 11, 857. [CrossRef] [PubMed]

99. Gasith, A.; Resh, V.H. Streams in Mediterranean climate regions: Abiotic influences and biotic responses to predictable seasonal events. Annu. Rev. Ecol. Syst. 1999, 30, 51-81. [CrossRef]

100. Bonada, N.; Resh, V.H. Mediterranean-climate streams and rivers: Geographically separated but ecologically comparable freshwater systems. Hydrobiologia 2013, 719, 1-29. [CrossRef]

101. Stromberg, J.C.; Boudell, J.A. Floods, drought, and seed mass of riparian plant species. J. Arid Environ. 2013, 97, 99-107. [CrossRef]

102. Bendix, J.; Cowell, C.M. Fire, floods and woody debris: Interactions between biotic and geomorphic processes. Geomorphology 2010, 116, 297-304. [CrossRef]

103. Arnaud, P.; Lavabre, J. La modélisation stochastique des pluies horaires et leur transformation en débits pour la prédétermination des crues. Rev. Des Sci. De L'eau/J. Water Sci. 2000, 13, 441-462. [CrossRef]

104. Lázaro, R.; Rodrigo, F.S.; Gutiérrez, L.; Domingo, F.; Puigdefábregas, J. Analysis of a 30-year rainfall record (1967-1997) in semi-arid SE Spain for implications on vegetation. J. Arid Environ. 2001, 48, 373-395. [CrossRef]

105. Mayes, J. Rainfall variability in the Maltese Islands: Changes, Causes and Consequences. Geography 2001, 86, 121-130.

106. Alpert, P.; Ben-Gai, T.; Baharad, A.; Benjamini, Y.; Yekutieli, D.; Colacino, M.; Diodato, L.; Ramis, C.; Homar, V.; Romero, R.; et al. The paradoxical increase of Mediterranean extreme daily rainfall in spite of decrease in total values. Geophys. Res. Lett. 2002, 29, 1536. [CrossRef]

107. Gabriele, S.; Villani, P. The estimation of rainfall frequency in a Mediterranean environment due to extraordinary combinations of hydrological and climatic conditions. IAHS Publ. 2002, 271, 45-50.

108. Homar, V.; Romero, R.; Ramis, C.; Alonso, S. Numerical study of the October 2000 torrential precipitation event over eastern Spain: Analysis of the synoptic-scale stationarity. Ann. Geophys. 2002, 20, 2047-2066. [CrossRef]

109. Obled, C.; Bontron, G.; Garçon, R. Quantitative precipitation forecasts: A statistical adaptation of model outputs through an analogues sorting approach. Atmos. Res. 2002, 63, 303-324. [CrossRef]

110. Rosso, R.; Rulli, M.C. An integrated simulation method for flash-flood risk assessment: 2 . Effects of changes in land-use under a historical perspective. Hydrol. Earth Syst. Sci. 2002, 6, 285-294. [CrossRef] 
111. Ayalon, A.; Bar-Matthews, M.; Kaufman, A. Climatic conditions during marine oxygen isotope stage 6 in the eastern Mediterranean region from the isotopic composition of speleothems of Soreq Cave, Israel. Geology 2002, 30, 303-306. [CrossRef]

112. Gonzalez-Hidalgo, J.C.; de Luis, M.; Raventós, J.; Sanchez, J.R. Daily rainfall trend in the Valencia Region of Spain. Theor. Appl. Climatol. 2003, 75, 117-130. [CrossRef]

113. Belmonte, A.M.C.; Beltrán, F.S. Flood events in Mediterranean ephemeral streams (ramblas) in Valencia region, Spain. Catena 2001, 45, 229-249. [CrossRef]

114. Alessandroni, M.G.; Remedia, G. The most severe floods of the Tiber River in Rome. IAHS Publ. 2002, $271,129-132$.

115. Rigo, T.; Llasat, M.D.C. Flash floods and heavy rain events in Catalonia: Analysis of the 1996-2000 period. IAHS Publ. 2003, 278, 269-275.

116. Neppel, L.; Bouvier, C.; Desbordes, M.; Vinet, F. A possible origin for the increase in floods in the Mediterranean region. Rev. Sci. Eau 2003, 16, 475-494.

117. Sala, M. Floods triggered by natural conditions and by human activities in a Mediterranean coastal environment. Geogr. Ann. A 2003, 85, 301-312. [CrossRef]

118. Palutikof, J.P.; Goodess, C.M.; Watkins, S.J.; Holt, T. Generating rainfall and temperature scenarios at multiple sites: Examples from the Mediterranean. J. Clim. 2002, 15, 3529-3548. [CrossRef]

119. Pinto, J.G. Influence of large-scale atmospheric circulation and baroclinic waves on the variability of mediterranean rainfall. Ph.D. Thesis, Universität zu Köln, Cologne, Germany, 2002.

120. Vandenschrick, G.; van Wesemael, B.; Frot, E.; Pulido-Bosch, A.; Molina, L.; Stiévenard, M.; Souchez, R. Using stable isotope analysis $\left(\delta \mathrm{D}\right.$ and $\left.\delta^{18} \mathrm{O}\right)$ to characterise the regional hydrology of the Sierra de Gador, south east Spain. J. Hydrol. 2002, 265, 43-55. [CrossRef]

121. Piras, M.; Mascaro, G.; Deidda, R.; Vivoni, E.R. Impacts of climate change on precipitation and discharge extremes through the use of statistical downscaling approaches in a Mediterranean basin. Sci. Total Environ. 2016, 543, 952-964. [CrossRef]

122. Padedda, B.M.; Pulina, S.; Magni, P.; Sechi, N.; Lugliè, A. Phytoplankton Dynamics in Relation to Environmental Changes in a Phytoplankton-Dominated Mediterranean Lagoon (Cabras Lagoon, Italy). Adv. Oceanogr. Limnol. 2012, 3, 147-169. [CrossRef]

123. Cristiano, E.; Urru, S.; Farris, S.; Ruggiu, D.; Deidda, R.; Viola, F. Analysis of potential benefits on flood mitigation of a CAM green roof in Mediterranean urban areas. Build. Environ. 2020, 183, 107179. [CrossRef]

124. Schiller, G.; Korol, L.; Shklar, G. Habitat effects on adaptive genetic variation in Pinus halepensis Mill. provenances. For. Genet. 2004, 11, 325-335.

125. Llorens, P.; Poyatos, R.; Muzylo, A.; Rubio, C.M.; Latron, J.; Delgado, J.; Gallart, F. Hydrology in a Mediterranean mountain environment-The Vallcebre research basins (North Eastern Spain). III. Vegetation and water fluxes. IAHS Publ. 2010, 336, 186-191.

126. Maxime, C.; Hendrik, D. Effects of climate on diameter growth of co-occurring Fagus sylvatica and Abies alba along an altitudinal gradient. Trees 2011, 25, 265-276. [CrossRef]

127. Coll, M.; Peñuelas, J.; Ninyerola, M.; Pons, X.; Carnicer, J. Multivariate effect gradients driving forest demographic responses in the Iberian Peninsula. Forest Ecol. Manag. 2013, 303, 195-209. [CrossRef]

128. Lempereur, M.; Martin-StPaul, N.K.; Damesin, C.; Joffre, R.; Ourcival, J.-M.; Rocheteau, A.; Rambla, S. Growth duration is a better predictor of stem increment than carbon supply in a Mediterranean oak forest: Implications for assessing forest productivity under climate change. New Phytol. 2015, 207, 579-590. [CrossRef]

129. García-Palacios, P.; Prieto, I.; Ourcival, J.-M.; Hättenschwiler, S. Disentangling the litter quality and soil microbial contribution to leaf and fine root litter decomposition responses to reduced rainfall. Ecosystems 2016, 19, 490-503. [CrossRef]

130. Misson, L.; Degueldre, D.; Collin, C.; Rodriguez, R.; Rocheteau, A.; Ourcival, J.-M.; Rambal, S. Phenological responses to extreme droughts in a Mediterranean forest. Glob. Chang. Biol. 2010, 17, 1036-1048. [CrossRef]

131. de Dios Miranda, J.; Jorquera, M.J.; Pugnaire, F.I. Phenological and reproductive responses of a semiarid shrub to pulsed watering. Plant Ecol. 2014, 215, 769-777. [CrossRef]

132. Liu, D.; Ogaya, R.; Barbeta, A.; Yang, X.; Peñuelas, J. Contrasting impacts of continuous moderate drought and episodic severe droughts on the aboveground-biomass increment and litterfall of three coexisting Mediterranean woody species. Glob. Change Biol. 2015, 21, 4196-4209. [CrossRef] [PubMed]

133. Joët, T.; Ourcival, J.-M.; Capelli, M.; Dussert, S.; Morin, X. Explanatory ecological factors for the persistence of desiccation-sensitive seeds in transient soil seed banks: Quercus ilex as a case study. Ann. Bot. 2016, 117, 165-176. [CrossRef] [PubMed]

134. Liu, D.; Estiarte, M.; Ogaya, R.; Yang, X.; Peñuelas, J. Shift in community structure in an early-successional Mediterranean shrubland driven by long-term experimental warming and drought and natural extreme droughts. Glob. Chang. Biol. 2017, 23, 4267-4279. [CrossRef]

135. Alon, M.; Sternberg, M. Effects of extreme drought on primary production, species composition and species diversity of a Mediterranean annual plant community. J. Veg. Sci. 2019, 30, 1045-1061. [CrossRef]

136. Gavinet, J.; Ourcival, J.-M.; Gauzere, J.; García de Jalón, L.; Limousin, J.-M. Drought mitigation by thinning: Benefits from the stem to the stand along 15 years of experimental rainfall exclusion in a holm oak coppice. Forest Ecol. Manag. 2020, $473,118266$. [CrossRef]

137. Cotrufo, M.F.; Alberti, G.; Inglima, I.; Marjanović, H.; LeCain, D.; Zaldei, A.; Peressotti, A.; Miglietta, F. Decreased summer drought affects plant productivity and soil carbon dynamics in a Mediterranean woodland. Biogeosciences 2011, 8, 2729-2739. [CrossRef] 
138. Linares, J.C.; Delgado-Huertas, A.; Carreira, J.A. Climatic trends and different drought adaptive capacity and vulnerability in a mixed Abies pinsapo-Pinus halepensis forest. Clim. Chang. 2011, 105, 67-90. [CrossRef]

139. Matías, L.; Zamora, R.; Castro, J. Sporadic rainy events are more critical than increasing of drought intensity for woody species recruitment in a Mediterranean community. Oecologia 2012, 169, 833-844. [CrossRef] [PubMed]

140. Barbeta, A.; Ogaya, R.; Peñuelas, J. Dampening effects of long-term experimental drought on growth and mortality rates of a Holm oak forest. Glob. Chang. Biol. 2013, 19, 3133-3144. [CrossRef] [PubMed]

141. De Dios Miranda, J.; Padilla, F.M.; Pugnaire, F.I. Response of a Mediterranean semiarid community to changing patterns of water supply. Perspect. Plant Ecol. Evol. Syst. 2009, 11, 255-266. [CrossRef]

142. De Dios Miranda, J.; Padilla, F.M.; Lázaro, R.; Pugnaire, F.I. Do changes in rainfall patterns affect semiarid annual plant communities? J. Veg. Sci. 2009, 20, 269-276. [CrossRef]

143. Besson, C.K.; Lobo-do-Vale, R.; Rodrigues, M.L.; Almeida, P.; Herd, A.; Grant, O.M.; David, T.S.; Schmidt, M.; Otieno, D.; Keenan, T.F.; et al. Cork oak physiological responses to manipulated water availability in a Mediterranean woodland. Agric. For. Meteorol. 2014, 184, 230-242. [CrossRef]

144. Ruiz-Labourdette, D.; Génova, M.; Schmitz, M.F.; Urrutia, R.; Pineda, F.D. Summer rainfall variability in European Mediterranean mountains from the sixteenth to the twentieth century reconstructed from tree rings. Int. J. Biometeorol. 2014, 58, 1627-1639. [CrossRef]

145. Rodríguez, A.; Durán, J.; Rey, A.; Boudouris, I.; Valladares, F.; Gallardo, A.; Yuste, J.C. Interactive effects of forest die-off and drying-rewetting cycles on C and N mineralization. Geoderma 2019, 333, 81-89. [CrossRef]

146. Ohana-Levi, N.; Givati, A.; Paz-Kagan, T.; Karnieli, A. Forest composition effect on wildfire pattern and runoff regime in a Mediterranean watershed. Ecohydrology 2017, 11, 1936. [CrossRef]

147. Cardil, A.; Vega-García, C.; Ascoli, D.; Molina-Terrén, D.M.; Silva, C.A.; Rodrigues, M. How does drought impact burned area in Mediterranean vegetation communities? Sci. Total Environ. 2019, 693, 133603. [CrossRef]

148. García-Llamas, P.; Suárez-Seoane, S.; Taboada, A.; Fernández-Manso, A.; Quintano, C.; Fernández-García, V.; FernándezGuisuraga, J.M.; Marcos, E.; Calvo, L. Environmental drivers of fire severity in extreme fire events that affect Mediterranean pine forest ecosystems. For. Ecol. Manag. 2019, 433, 24-32. [CrossRef]

149. Delač, D.; Pereira, P.; Bogunović, I.; Kisić, I. Short-Term Effects of Pile Burn on N Dynamic and N Loss in Mediterranean Croatia. Agronomy 2020, 10, 1340. [CrossRef]

150. Morán-Ordóñez, A.; Duane, A.; Gil-Tena, A.; De Cáceres, M.; Aquilué, N.; Guerra, C.; Geijzendorffer, I.R.; Fortin, M.-J.; Brotons, L. Future impact of climate extremes in the Mediterranean: Soil erosion projections when fire and extreme rainfall meet. Land Degrad. Dev. 2020, 31, 3040-3054. [CrossRef]

151. Rinat, Y.; Marra, F.; Zoccatelli, D.; Morin, E. Controls of flash flood peak discharge in Mediterranean basins and the special role of runoff-contributing areas. J. Hydrol. 2018, 565, 846-860. [CrossRef]

152. Ballesteros-Canovas, J.A.; Bombino, G.; D’Agostino, D.; Denisi, P.; Labate, A.; Stoffel, M.; Zema, D.A.; Zimbone, S.M. Tree-ring based, regional-scale reconstruction of flash floods in Mediterranean mountain torrents. Catena 2020, 189, 104481. [CrossRef]

153. Marques, I.G.; Campelo, F.; Rivaes, R.; Albuquerque, A.; Ferreira, M.T.; Rodríguez-González, P.M. Tree rings reveal long-term changes in growth resilience in Southern European riparian forests. Dendrochronologia 2018, 52, 167-176. [CrossRef]

154. Bertini, G.; Amoriello, T.; Fabbio, G.; Piovosi, M. Forest growth and climate change: Evidences from the ICP-Forests intensive monitoring in Italy. iForest 2011, 4, 262-267. [CrossRef]

155. Pilaš, I.; Medved, I.; Medak, J.; Medak, D. Response strategies of the main forest types to climatic anomalies across Croatian biogeographic regions inferred from FAPAR remote sensing data. Forest Ecol. Manag. 2014, 326, 58-78. [CrossRef]

156. Costa-e-Silva, F.; Correia, A.C.; Piayda, A.; Dubbert, M.; Rebmann, C.; Cuntz, M.; Werner, C.; David, J.S.; Pereira, J.S. Effects of an extremely dry winter on net ecosystem carbon exchange and tree phenology at a cork oak woodland. Agr. For. Meteorol. 2015, 204, 48-57. [CrossRef]

157. Kim, H.N.; Jin, H.Y.; Kwak, M.J.; Khaine, I.; You, H.N.; Lee, T.Y.; Ahn, T.H.; Woo, S.Y. Why does Quercus suber species decline in Mediterranean areas? J. Asia-Pac. Biodivers. 2017, 10, 337-341. [CrossRef]

158. Vacca, A.; Aru, F.; Ollesch, G. Short-term Impact of Coppice Management on Soil in a Quercus ilex 1. Stand of Sardinia. Land Degrad. Dev. 2017, 28, 553-565. [CrossRef]

159. Aguilar, C.; Guzmán, E.; Burguet, M.; Polo, M.J.; Taguas, E.V. Hydrological Response of a Semiarid Olive Orchard Microcatchment Under Theoretical Climate Change Scenarios. Soil Sci. 2016, 181, 283-292. [CrossRef]

160. Uzun, A.; Ustaoğlu, B. Impacts of El Nino Southern Oscillation (ENSO) and North Atlantic Oscillation (NAO) on the Olive Yield in the Mediterranean Region, Turkey. In Proceedings of the 8th International Conference on Agro-Geoinformatics (AgroGeoinformatics), Istanbul, Turkey, 16-19 July 2019; pp. 1-6. [CrossRef]

161. Rodríguez, B.C.; Zuazo, V.H.D.; Rodríguez, M.S.; Ruiz, B.G.; García-Tejero, I.F. Soil Erosion and the Efficiency of the Conservation Measures in Mediterranean Hillslope Farming (SE Spain). Eurasian Soil Sci. 2021, 54, 792-806. [CrossRef]

162. Palese, A.M.; Ringersma, J.; Baartman, J.E.M.; Peters, P.; Xiloyannins, C. Runoff and sediment yield of tilled and spontaneous grass-covered olive groves grown on sloping land. Soil Res. 2015, 53, 542-552. [CrossRef]

163. Ramos, M.C. Soil losses in rainfed Mediterranean vineyards under climate changes scenarios. The effects of drainage terraces. Agriculture 2016, 1, 124-143. [CrossRef] 
164. Comino, J.R.; Senciales, J.M.; Ramos, M.C.; Martínez-Casasnovas, J.A.; Lasanta, T.; Brevik, E.C.; Ries, J.B.; Sinoga, J.D.R. Understanding soil erosion processes in Mediterranean sloping vineyards (Montes de Málaga, Spain). Geoderma 2017, 296, 47-59. [CrossRef]

165. Cerdà, A.; Keesstra, S.D.; Rodrigo-Comino, J.; Novara, A.; Pereira, P.; Brevik, E.; Giménez-Morera, A.; Fernández-Raga, M.; Pulido, M.; di Prima, S.; et al. Runoff initiation, soil detachment and connectivity are enhanced as a consequence of vineyards plantations. J. Environ. Manag. 2017, 202, 268-275. [CrossRef]

166. Comino, J.R.; Sinoga, J.D.R.; González, J.M.S.; Guerra-Merchán, A.; Seeger, M.; Ries, J.B. High variability of soil erosion and hydrological processes in Mediterranean hillslope vineyards (Montes de Málaga, Spain). Catena 2016, 145, 274-284. [CrossRef]

167. Lenz, T.I.; Facelli, J.M. Correlations between environmental factors, the biomass of exotic annual grasses and the frequency of native perennial grasses. Aust. J. Bot. 2006, 54, 655-667. [CrossRef]

168. Castro, S.P.; Cleland, E.E.; Wagner, R.; Al Sawad, R.; Lipson, D.A. Soil microbial responses to drought and exotic plants shift carbon metabolism. ISME J. 2019, 13, 1776-1787. [CrossRef]

169. Godfree, R.C.; Knerr, N.; Godfree, D.; Busby, J.; Robertson, B.; Encinas-Viso, F. Historical reconstruction unveils the risk of mass mortality and ecosystem collapse during pancontinental megadrought. Proc. Natl. Acad. Sci. USA 2019, 116, 15580-15589. [CrossRef]

170. Lavorel, S. Ecological diversity and resilience of Mediterranean vegetation to disturbance. Divers. Distrib. 1999, 5, 3-13. [CrossRef]

171. Le Houérou, H.N. Global change: Population, land-use and vegetation in the Mediterranean Basin by the mid-21st century. In Greenhouse Effect, Sea Level and Drought; Springer: Dordrecht, The Netherlands, 1990; pp. 301-367.

172. Pausas, J.G. Response of plant functional types to changes in the fire regime in Mediterranean ecosystems: A simulation approach. J. Veg. Sci. 1999, 10, 717-722. [CrossRef]

173. Pausas, J.G. Resprouting of Quercus suber in NE Spain after fire. J. Veg. Sci. 1997, 8, 703-706. [CrossRef]

174. Pereira, J.S.; Chaves, M.M. Plant responses to drought under climate change in Mediterranean-type ecosystems. In Global Change and Mediterranean-Type Ecosystems; Springer: New York, NY, USA, 1995; pp. 140-160.

175. Rosenzweig, C.; Tubiello, F.N. Impacts of Global Climate Change on Mediterranean Agrigulture: Current Methodologies and Future Directions. An Introductory Essay. Mitig. Adapt. Strateg. Glob. Chang. 1997, 1, 219-232. [CrossRef]

176. Cossu, A.; De Waele, J.; Di Gregorio, F. Coastal karst geomorphosites at risk? A case study: The floods of 6-11 December 2004 in central-east Sardinia. Geol. Soc. Lond. Spec. Publ. 2007, 279, 85-95. [CrossRef]

177. De Waele, J.; Martina, M.L.V.; Sanna, L.; Cabras, S.; Cossu, Q.A. Flash flood hydrology in karstic terrain: Flumineddu Canyon, central-east Sardinia. Geomorphology 2010, 120, 162-173. [CrossRef]

178. Cittadini, M.; Mancini, M.; Tilocca, G.; Fresia, I.; Ravazzani, G.; Malcotti, R. Flash Flood and Pluvial Flooding. Why Sardinia? Ispra, Ministero dell'Ambiente, Regione Sardegna Agenzia di Distretto Idrografico: Cagliari, Italy, 2010.

179. Frongia, S.; Ruiu, A.; Sechi, G.M. Evaluation of water depth-damage functions in built-up areas in Sardinia (Italy). Water Utility J. 2018, 20,37-48.

180. Niedda, M.; Amponsah, W.; Marchi, L.; Zoccatelli, D.; Marra, F.; Crema, S.; Pirastru, M.; Marrosu, R.; Borga, M. Il ciclone Cleopatra del 18 novembre 2013 in Sardegna: Analisi e modellazione dell'evento di piena. Quad. Idronomia Mont. 2014, 32 , 47-58.

181. Righini, M.; Surian, N.; Wohl, E.; Marchi, L.; Comiti, F.; Amponsah, W.; Borga, M. Geomorphic response to an extreme flood in two Mediterranean rivers (northeastern Sardinia, Italy): Analysis of controlling factors. Geomorphology 2017, 290, 184-199. [CrossRef]

182. Franci, F.; Boccardo, P.; Mandanici, E.; Roveri, E.; Bitelli, G. Flood mapping using VHR satellite imagery: A comparison between different classification approaches. In Earth Resources and Environmental Remote Sensing/GIS Applications VII; SPIE: Edinburgh, UK, 2016; Volume 10005, pp. 1-9. [CrossRef]

183. Faccini, F.; Luino, F.; Paliaga, G.; Roccati, A.; Turconi, L. Flash Flood Events along the West Mediterranean Coasts: Inundations of Urbanized Areas Conditioned by Anthropic Impacts. Land 2021, 10, 620. [CrossRef]

184. Caloiero, T.; Coscarelli, R.; Gaudio, R. Spatial and temporal variability of daily precipitation concentration in the Sardinia region (Italy). Int. J. Climatol. 2019, 39, 5006-5021. [CrossRef]

185. Bodini, A.; Cossu, Q.A. Vulnerability assessment of Central-East Sardinia (Italy) to extreme rainfall events. Nat. Hazards Earth Syst. Sci. 2010, 10, 61-72. [CrossRef] 